\title{
16. ISOTOPIC STRATIGRAPHY OF AMAZON FAN SEDIMENTS ${ }^{1}$
}

\author{
William J. Showers, ${ }^{2}$ Ralph Schneider, ${ }^{3}$ Naja Mikkelson, ${ }^{4}$ and Mark Maslin ${ }^{5}$
}

\begin{abstract}
$\delta^{18} \mathrm{O}$ stratigraphies of planktonic foraminifers were completed for 17 sites drilled on the Amazon Fan during Leg 155 (March-May 1994). These sites penetrated sediments of the last glacial and, for the first time, sediments of the previous interglacial on the Amazon Fan. Downslope, sediment depositional processes and hiatuses dominate the record in sites from the lower portion of the fan making the construction of age models from isotopic data alone problematic. Sites from the central axis of the fan have extremely high sedimentation rates. Age models could only be constructed with isotopic data at these sites into isotopic Stages 2-3, because sediment reworking processes dominate the record in sediments older than Stage 3 (>25 k.y.). High resolution isotopic records were obtained in the hemipelagic portions of the mud-rich upper fan (Sites 937 through 939 ) and from a site located to the west of the central axis of the fan (Site 942). Age models constructed from these isotopic stratigraphies show that sediments accumulated at rates up to $30 \mathrm{~m} / \mathrm{k}$.y. on the central fan during the last glacial lowstand. On the far western portion of the fan at Site 942, sedimentation rates are higher in the interglacials than during the last glacial period. Continental margin drilling can yield high resolution isotopic records if sites are carefully chosen to avoid areas where depositional processes are dominated by sediment gravity flows and reworking.
\end{abstract}

\section{INTRODUCTION}

Understanding and characterizing the paleoceanographic and paleoclimatic changes that occurred during the last deglaciation and previous interglacial has become increasingly important because of links between atmospheric greenhouse gas concentrations and changes in oceanic circulation, chemistry, and climate (Broecker and Takahashi, 1984; Broecker et al., 1985). The role that oceans play in global warming due to the increase of greenhouse gases in the atmosphere is an unanswered question. It has been forecasted that the oceans will absorb vast quantities of heat and $\mathrm{CO}_{2}$ and reduce the global warming resulting from anthropogenic $\mathrm{CO}_{2}$ emissions. The absorption or ventilation of atmospheric $\mathrm{CO}_{2}$ in the oceans is linked to the global oceanic conveyor circulation (Gordon 1986; Broecker et al., 1992). Ice cores record abrupt climate change events known as Dansgaard-Oeschger events (Dansgaard et al., 1983). These ice core climatic events correlate well to lithic peaks in the North Atlantic marine record, demonstrating that they represent changes in oceanic conveyor circulation and rapid reorganizations of the ocean/atmospheric circulation (Bond et al., 1992, 1993; Bond and Lotti, 1995; Fronval et al., 1995; Haflidason et al., 1995). However, discrepancies between different records from Greenland ice cores raise new questions concerning the mechanisms of late Quaternary climate change (Dansgaard et al., 1993; Alley et al., 1993). To resolve these questions, high resolution marine records are needed (McManus et al., 1994). High resolution marine records have been obtained from sediment drifts in the deep North Atlantic (Keigwin and Jones, 1994, 1989; Haskell et al., 1991) and from continental margins (Keigwin and Jones, 1995; Fronval et al., 1995; Andrews et al., 1994). Oceanic margins are widely recognized as important areas of global primary

'Flood, R.D., Piper, D.J.W., Klaus, A., and Peterson, L.C. (Eds.), 1997. Proc. ODP, Sci. Results, 155: College Station, TX (Ocean Drilling Program).

${ }^{2}$ Department of Marine, Earth and Atmospheric Sciences, North Carolina State University, Raleigh NC 27695-8208 U.S.A. W_Showers@ NCSU.EDU

${ }^{3}$ Fachbereich Geowissenschaften, Universität Bremen, Bremen, Federal Republic of Germany.

${ }^{4}$ Geological Survey of Denmark, Thora Vej 8, Copenhagen, Denmark.

${ }^{5}$ Geologisch Paläontologisches Institut und Museum, Universität Kiel, Federal Republic of Germany. (Present address: Department of Geography, University College London, 26 Bedford Way, London WC1H 0AP, United Kingdom). production (Koblentz-Mishke et al., 1970; Berger et al., 1989) and have high sedimentation rates. But margins are also areas where sediment gravity flows (slumping sliding, turbidity currents, debris flows) are prevalent, especially on submarine fans (Bouma et al., 1989). These dynamic sedimentation processes disturb the chronostratigraphic continuity of margin records, and thus these areas are underrepresented in paleoceanographic and paleoclimatic reconstructions (Keigwin and Jones, 1995). Sedimentation processes on the Amazon Fan adjacent to the Brazilian continental margin are controlled by glacio-eustatic sea-level fluctuations (Damuth and Kumar, 1975; Damuth, 1977; Damuth et al., 1988; Flood, Piper, Klaus, et al., 1995). Terrigenous sediments discharged by the Amazon River are trapped on the wide continental shelf during interglacials (Nittrouer and DeMaster, 1986), and are discharged directly to the Amazon Fan during low sea-level stands via the head of Amazon submarine canyon. A complex pattern of submarine channels and debris flows is found on the surface of the Amazon Fan (Flood, Piper, Klaus, et al., 1995; Fig. 1). Previous piston coring of the fan resulted in short cores (10 m or less) with sedimentation rates up to $175 \mathrm{~cm} / \mathrm{k} . \mathrm{y}$. (Showers and Bevis, 1988). The purpose of this study was to sample deeper Amazon Fan sediments to obtain isotopic records back into the last glacial and previous interglacial period.

\section{METHODS}

Sites 930 through 946 were drilled on the Brazilian continental margin during Leg 155, and over $4000 \mathrm{~m}$ of sediment was recovered from March through May 1994 (Fig. 1). Samples with a 20- $\mathrm{cm}^{3}$ volume were taken for isotopic analysis of foraminifers every $50 \mathrm{~cm}$ in the upper and middle fan cores. Samples with a $60-\mathrm{cm}^{3}$ volume were taken for isotopic analysis of foraminifers every $150 \mathrm{~cm}$ in the lower fan cores because of reduced microfossil abundances in the coarser grained sediments. Samples with a volume of 200 to $1500 \mathrm{~cm}^{3}$ were taken from every core catcher for biostratigraphy and isotopic analysis. Foraminifer abundance and preservation were estimated visually by examination under a stereo-microscope according to the criteria of Flood, Piper, Klaus, et al. (1995). Amazon Fan sediments contain significant amounts of methane that resulted in core expansion and core gaps. Core depths for shipboard samples were therefore adjusted for core gaps and core expansion with a correction program developed 


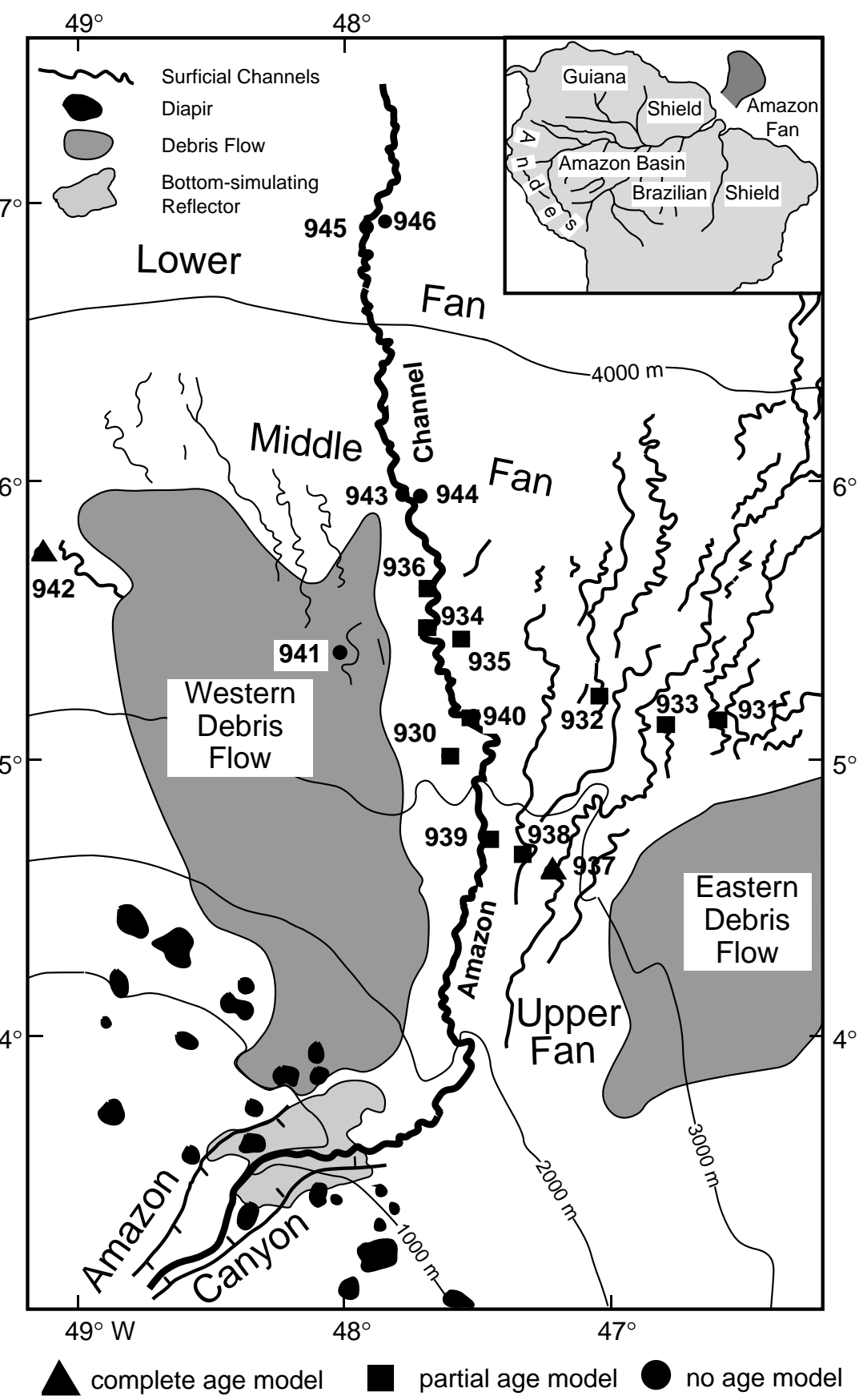

by D. Piper (see "Preface," this volume). Isotopic analyses for Sites 938 and 940 were completed at Universität Bremen, analyses for Sites 932 and 933 were completed at Universität Kiel, and analyses for the rest of the sites drilled during Leg 155 were completed at North Carolina State University. Samples were freeze dried, disaggregated in tap water, washed with hot water over a $63-\mu \mathrm{m}$ sieve, and then air dried at $65^{\circ} \mathrm{C}$. Specimens of monospecific planktonic foraminifers (Globigerinoides sacculifer, Globigerinoides trilobus, or Globigerinoides ruber) were hand picked out of the $>125-\mu \mathrm{m}$ size fraction. Because of the low abundance of foraminifers in Amazon Fan sediments, the size fraction separated for isotopic analysis could not be further restricted. When foraminifer abundance was high, 20 specimens were mixed together and crushed, and small duplicate aliquots from the same sample were analyzed. When abundances were low, as few as $3-5$ specimens were analyzed. In all three labs, a Kiel Autocarbonate device attached to a Finnigan MAT 251 ratio mass spectrometer was used to prepare and isotopically analyze the samples. Isotopic reproducibility on replicates of NBS standards for the Kiel Autocarbonate device is +0.05 per milliliter for $\delta^{13} \mathrm{C}$ and +0.07 per milliliter for $\delta^{18} \mathrm{O}$. Isotopic reproducibility on replicates of foraminifer samples is generally higher than standards, ranging from +0.1 to 0.15 per milliliter for $\delta^{13} \mathrm{C}$ and $\delta^{18} \mathrm{O}$.

\section{RESULTS}

On the Amazon Fan, foraminifer abundance and preservation varied with lithostratigraphic unit (Fig 2). Foraminifers were abundant 


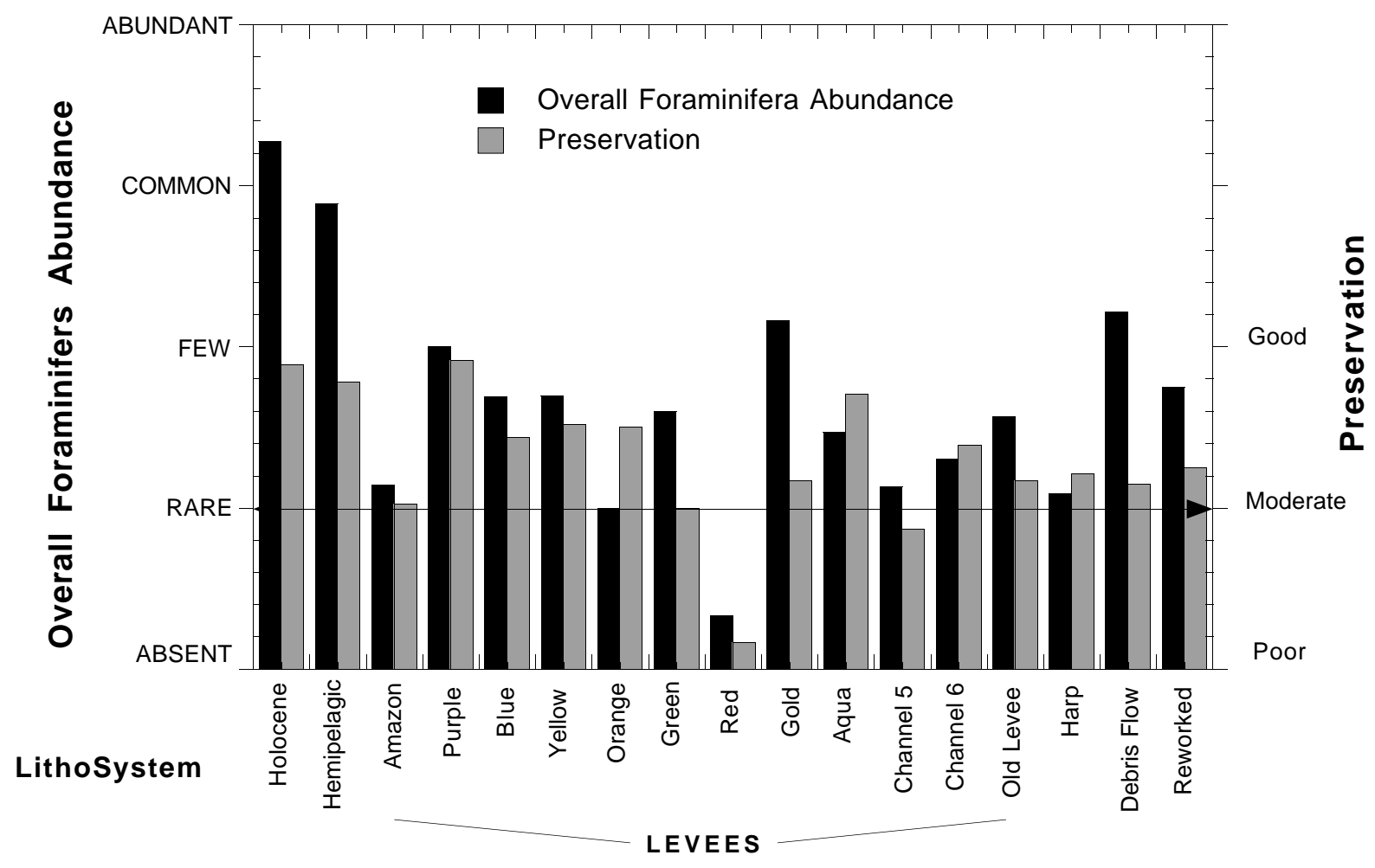

Figure 2. Planktonic foraminifer abundance and preservation varies with lithologic unit. Only the Red Channel-levee System could not be characterized isotopically.

in Holocene and hemipelagic sediments, but decreased dramatically in the glacial lowstand sediments. Preservation was moderate to good in all lithostratigraphic units except for the Red Channel-levee System, where only a few dissolved foraminifers were present. Overall, abundances were low and the most common abundance of foraminifers in Amazon Fan sediments were few to rare (Fig. 3). Isotopic analyses were completed on 3055 samples for this study, and the isotopic results are listed in the Appendix (on CD-ROM in the back pocket of this volume). Biostratigraphic and paleomagnetic datums are limited at these sites (Flood, Piper, Klaus, et al., 1995) and in many cases $\delta^{18} \mathrm{O}$ stratigraphies have played an important role in developing chronostratigraphic models. Isotopic events recognized in this paper were identified by comparison to the $\delta^{18} \mathrm{O}$ stacked chronologies of Imbrie et al. (1984), Prell et al. (1986), Pisias et al. (1984), and Martinson et al. (1987). These events identified for Leg 155 sites are listed in Table 1. In addition, the Younger Dryas Event is well represented in the upper portion of some of these sites. The age used for the end of this $\delta^{18} \mathrm{O}$ event was $11.0 \mathrm{ka}$ (Flower and Kennett, 1990). The reappearance of Globorotalia tumida was recognized in the hemipelagic portion at the top of most of the sites and has been accelerator mass spectrometry (AMS- ${ }^{14} \mathrm{C}$ ) dated at 9-7.3 ka (G. Jones, pers. comm., 1994). Below is a brief discussion of the $\delta^{18} \mathrm{O}$ stratigraphy at each site.

\section{Site 930}

Site 930 was drilled on the upper part of the Amazon Fan in between levees of the Amazon Channel and the buried Purple Channel (Fig. 1). Isotopic events 1.1 to 3.0 were identified in the upper $125 \mathrm{~m}$ of the hole (Fig. 4). Sedimentation rates vary from $~ 90 \mathrm{~cm} / \mathrm{k}$.y. at the top of the hole to $>2500 \mathrm{~cm} / \mathrm{k}$.y. below 100 meters below seafloor (mbsf). Sedimentation rates increase in a linear fashion downhole except for a rapid increase in rates during the last deglaciation. The $\mathrm{Y}_{\mathrm{P}}$ obliq 40 k.y. biostratigraphic datum (Prell and Damuth, 1978) is found immediately below the 3.0 isotopic event. This biostratigraphic datum should normally be located between isotopic events 3.1 and 3.13 , but is suspect here since it is based on the occurrence of only one specimen. A mass transport unit found at the base of the hole in the Orange Channel-levee System has high benthic foraminifer abundance, but yielded no isotopic chronostratigraphic information.

\section{Site 931}

Site 931 was drilled on a buried levee of Channel-levee System 5 (Fig. 1) and passed down into high-amplitude reflection packets (HARPs) and a debris flow deposit that separates the Channel-levee System 5 from the Bottom Levee Complex. Isotopic events 2.2 and 2.21 were tentatively identified in the Channel-levee System 5 (Fig 5). Isotopic evidence for the Holocene and deglaciation is lacking in the upper portion of the hole, whereas low foraminifer abundance precluded development of a detailed stratigraphy in the lower portion of the Channel 5 levee. The HARPs, high-amplitude reflections (HARs), and debris flow deposits yielded no isotopic chronostratigraphic information. Though isotopic datums are few, sedimentation rates in the upper part of the hole are clearly low $(\sim 6 \mathrm{~cm} / \mathrm{k} . \mathrm{y}$.$) and in-$ crease greatly $(>3000 \mathrm{~cm} / \mathrm{k} . \mathrm{y}$.) during the interval that corresponds to isotopic Stage 2.

\section{Site 932}

Site 932 was drilled into hemipelagic sediments east of the crest of the Channel-levee System 6B (Fig. 1). Low foraminifer abundanc- 


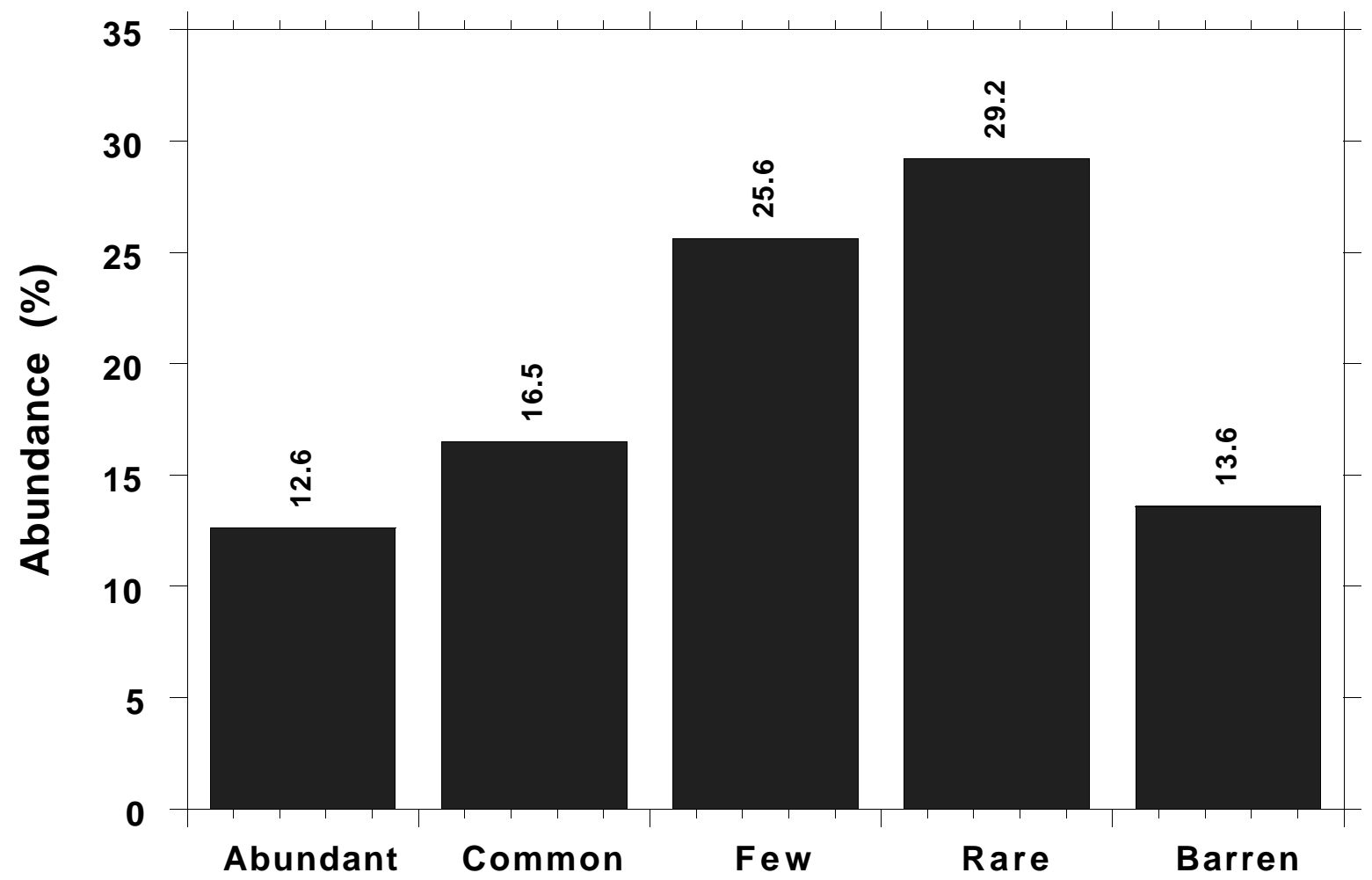

Figure 3. Overall planktonic foraminifer abundances from Amazon Fan sediments. The most common abundance categories were few and rare.

Table 1. Depths and ages of $\delta^{18} \mathrm{O}$ events used to construct age models in Leg 155 holes.

\begin{tabular}{|c|c|c|c|c|c|c|c|c|c|c|c|c|c|c|c|c|c|c|}
\hline \multirow[b]{2}{*}{ Control point } & \multirow{2}{*}{$\begin{array}{c}\text { Age } \\
\text { (k.y.) }\end{array}$} & \multicolumn{17}{|c|}{ Hole } \\
\hline & & $930 \mathrm{~B}$ & 931B & $932 \mathrm{~A}$ & $933 \mathrm{~A}$ & $934 \mathrm{~A}$ & $935 \mathrm{~A}$ & $936 \mathrm{~A}$ & 937B & $938 \mathrm{~A}$ & $939 \mathrm{~B}$ & $940 \mathrm{~A}$ & $941 \mathrm{~A}$ & $942 \mathrm{~A}$ & $943 \mathrm{~A}$ & $944 \mathrm{~A}$ & $945 \mathrm{~A}$ & $946 \mathrm{~A}$ \\
\hline 1.1 & 2.32 & 0 & & & & & & & & & & & & 0.07 & & & & \\
\hline Tumida AD & 9.00 & 8.42 & & & & 0.9 & 0.53 & 2.7 & 3.2 & & 3.99 & 2.12 & & 2.25 & 1.64 & 0.5 & 1.23 & 0.24 \\
\hline YD & 11.00 & 15.35 & & & & 8.61 & & 28.02 & & & 9.2 & 58.55 & 3.6 & 4 & & 2.2 & & \\
\hline 2.2 & 17.85 & 28.42 & 1 & 3.72 & 3.7 & 89.7 & 28.2 & 61.16 & 10.1 & 22.11 & 38.57 & 167.48 & 7.58 & 6.5 & 2.26 & 58.83 & & 22.6 \\
\hline 2.21 & 19.22 & 37.5 & 46.89 & & 5.88 & & 35.2 & & 15.3 & 32.49 & 61.49 & & 10.47 & & & 65.35 & & \\
\hline 2.23 & 23.17 & 100.6 & & & 12.27 & & 93.47 & & & 106.16 & & & & & & & & \\
\hline 3 & 24.11 & 124.92 & & & 16.66 & & 104.03 & & 125.8 & 135.05 & & & & & & & & \\
\hline 3.1 & 25.42 & & & & & & & & & & & & & 11 & & & & \\
\hline 3.13 & 43.88 & & & & & & & & & & & & & 15.47 & & & & \\
\hline 3.3 & 50.21 & & & & & & 200.4 & & & & & & & 17.88 & & & & \\
\hline 3.31 & 55.45 & & & & & & & & & & & & & 18.84 & & & & \\
\hline 4.22 & 64.09 & & & & & & & & & & & & & 19.35 & & & & \\
\hline 4.23 & 68.83 & & & & & & & & & & & & & 20.81 & & & & \\
\hline 4.24 & 70.82 & & & & & & & & & & & & & 21.27 & & & & \\
\hline $\begin{array}{l}4.14 \\
5.1\end{array}$ & 79.25 & & & & & & & & & & & & & 28.67 & & & & \\
\hline $\begin{array}{l}5.1 \\
5.2\end{array}$ & 90.95 & & & & & & & & & & & & & 37.19 & & & & \\
\hline 5.3 & 99.38 & & & & & & & & & & & & & 41.14 & & & & \\
\hline 5.4 & 110.79 & & & & & & & & & & & & & 55.29 & & & & \\
\hline 5.5 & 123.82 & & & & & & & & & & & & & 65.74 & & & & \\
\hline 6.2 & 135.10 & & & & & & & & & & & & & 70.5 & & & & \\
\hline 6.3 & 142.28 & & & & & & & & & & & & & 77.25 & & & & \\
\hline 6.4 & 152.58 & & & & & & & & & & & & & & & & & \\
\hline
\end{tabular}

es precluded the development of an isotopic stratigraphy in the bottom of the hole. Isotopic event 2.2 was tentatively assigned in the upper 3-7 $\mathrm{m}$ of the hole (Fig. 6), though comparison of data from two species of planktonic foraminifers (G. ruber and G. trilobus) suggest different depths for the same event. Because of the noisy isotopic trends in these data, an age model based on isotopic data alone could not be developed. Maslin et al. (this volume) construct a chronology based on identification of paleomagnetic excursions and recognition of distinctive patterns in the secular variation of magnetic intensity.

\section{Site 933}

Site 933 was drilled on the eastern flank of the Yellow Channellevee System (Fig. 1) and drilled through Channel-levee Systems 5, $6 \mathrm{~A}$, and $6 \mathrm{~B}$, a debris flow deposit, and finally into the Bottom Levee Complex at the bottom of the hole. Isotopic events 2.2 through 3.0 were identified in the upper $20 \mathrm{~m}$ of the hole, which contain a good record of isotopic Stage 2 (Fig. 7). Below $20 \mathrm{mbsf}$, the hole yielded no useful isotopic chronostratigraphic information because foramin- 


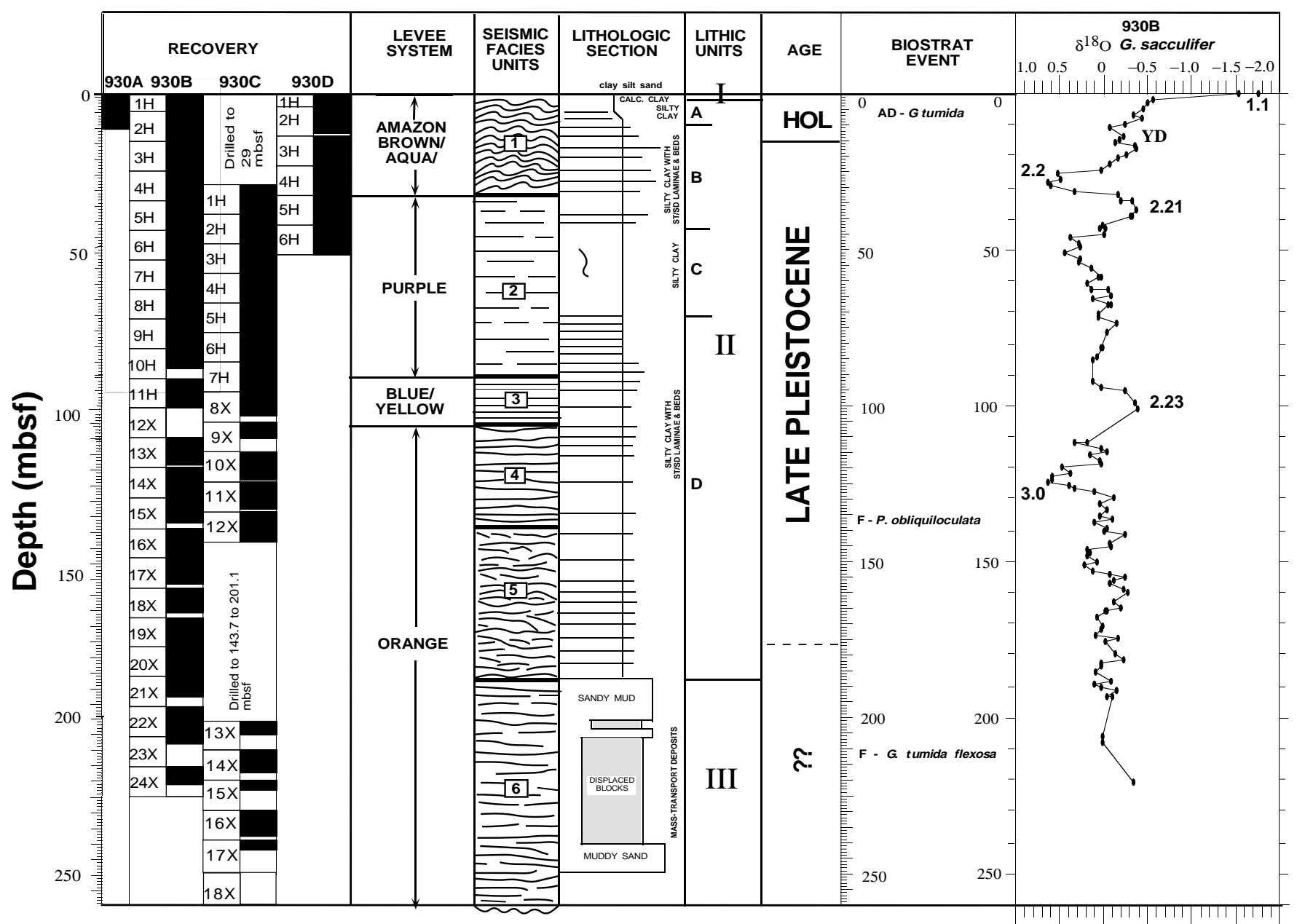

Figure 4. Summary of the $\delta^{18} \mathrm{O}$ stratigraphy with the lithostratigraphy, seismic stratigraphy, and biostratigraphy for Hole $930 \mathrm{~B}$.

ifer abundances were low and the downcore isotopic signal was noisy. Sedimentation rates in the upper portion of the hole average about $20 \mathrm{~cm} / \mathrm{k} . \mathrm{y}$., increasing to $>400 \mathrm{~cm} / \mathrm{k} . \mathrm{y}$. at $\sim 16 \mathrm{mbsf}$.

\section{Site 934}

Site 934 was drilled into a cutoff meander of the Amazon Channel in the middle portion of the fan (Fig. 1). Hemipelagic sediments grade down into overbank turbidites, muddy mass flow deposits, channel floor deposits, and finally prechannel deposits. Low foraminifer abundances preclude the development of a detailed isotopic chronostratigraphy. The Younger Dryas Event was recognized at the top of the hole and the 2.2 event appears to be found near the bottom of the hole at about $90 \mathrm{mbsf}$ (Fig. 8). Sedimentation rates at Site 934 vary from $10 \mathrm{~cm} / \mathrm{k} . \mathrm{y}$. at the top of the hole to $>1100 \mathrm{~cm} / \mathrm{k} . \mathrm{y}$. in Stage 2.

\section{Site 935}

Site 935 was drilled into the flank of the Aqua Channel-levee System and sampled the Amazon and Brown Channel-levee Systems, underlying HARPs, Unit R Debris Flow, and the Green Channellevee System of the Lower Levee Complex (Fig. 1). Isotopic events 2.2 to 3.3 were identified in sediments above the Unit R Debris Flow, and this site contains recognizable records of Stages 2 and 3 (Fig. 9).
Below the Unit R Debris Flow, the hole yielded no interpretable isotopic record. Sedimentation rates at this site appear to average about $6 \mathrm{~cm} / \mathrm{k} . \mathrm{y}$. in the upper part of the hole, and increase below the deglaciation where sedimentation rates vary greatly $(\sim 300-1500 \mathrm{~cm} / \mathrm{k} . \mathrm{y}$.) in Stage 2.

\section{Site 936}

Site 936 was located on the western levee of the Amazon Channel (Fig. 1) and drilled through the Unit R Debris Flow, the Red Channellevee System of the Middle Levee Complex, and the Gold Channellevee System of the Lower Levee Complex. The Younger Dryas and isotopic events 2.2 were identified in the upper $60 \mathrm{~m}$ of the hole (Fig 10). Poor core recovery in the Brown and Aqua Channels precluded the construction of an isotopic stratigraphy. The hole yielded no isotopic chronostratigraphic information in or below the Unit R Debris Flow. Sedimentation rates average about $30 \mathrm{~cm} / \mathrm{k} . \mathrm{y}$. in the upper portion of the hole, and vary from $\sim 300$ to $375 \mathrm{~cm} / \mathrm{k}$.y. between the deglaciation and in isotopic Stage 2.

\section{Site 937}

Site 937 was drilled on the upper portion of the eastern Amazon Fan on the western levee of the Yellow Channel-levee System (Fig 1). Isotopic events 2.2 to 3.01 were identified at this site (Fig. 11). 


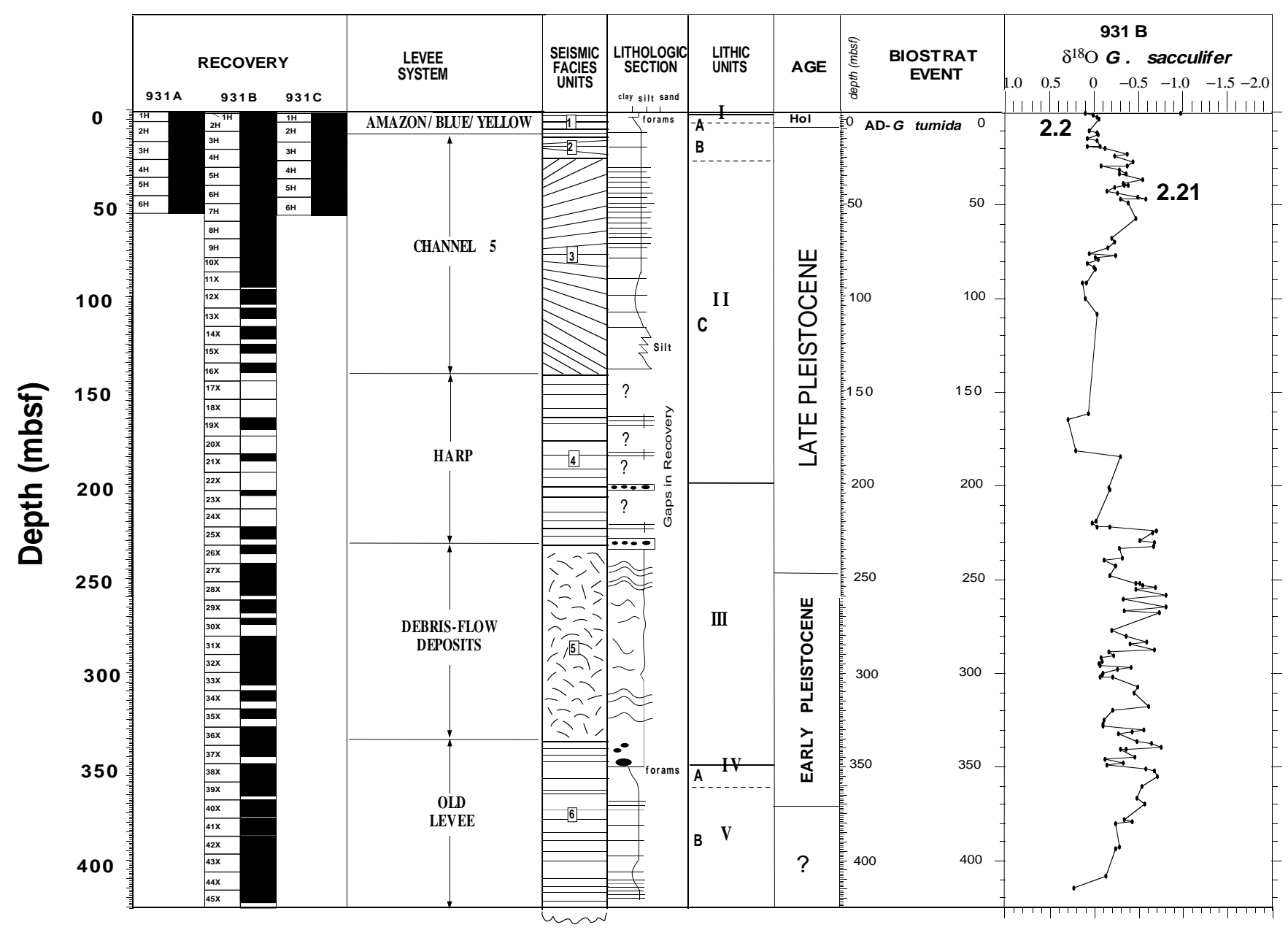

Figure 5. Summary of the $\delta^{18} \mathrm{O}$ stratigraphy with the lithostratigraphy, seismic stratigraphy, and biostratigraphy for Hole 931B.

The Holocene and deglacial portion of this record is condensed, with a possible Younger Dryas Event at $3 \mathrm{~m}$. This site contains a greatly expanded record of isotopic Stage 2. Deglacial sedimentation rates are $\sim 30 \mathrm{~cm} / \mathrm{k}$.y. and appear to vary in isotopic Stage 2 from $\sim 80$ to $>2200 \mathrm{~cm} / \mathrm{k}$.y., based on the recognized $\delta^{18} \mathrm{O}$ datums. Isotopic event 3.01 at the bottom of the hole does not have an orbitally tuned age assigned to it, so sedimentation rates cannot be calculated for the bottom of the hole in the Yellow Channel-levee System. However, it is likely the apparent increase in sedimentation rates between events 2.23 and 3.0 is associated with the top of the Yellow Channel-levee complex.

\section{Site 938}

Site 938 was drilled into the western levee of the Blue Channellevee System (Fig. 1) and sampled the Channel 5/Yellow System and Channel 6 at the bottom of the hole. The Younger Dryas and isotopic events 2.2 to 3.0 were identified at this site (Fig. 12). Isotopic event 3.0 was found very close to the $\mathrm{Y}_{\mathrm{P} \text {. obliq }} 40$ k.y. biostratigraphic datum (Prell and Damuth, 1978). In this core, the 3.0 event was found associated with the top of the Yellow Channel-levee System. No useful isotopic stratigraphic data were obtained in the lower $150 \mathrm{~m}$ of the hole in Channel-levee Systems 5/6. Sedimentation rates vary during the deglaciation from $\sim 75$ to $200 \mathrm{~cm} / \mathrm{k}$.y. and vary in isotopic Stage 2 from 750 to $3000 \mathrm{~cm} / \mathrm{k} . \mathrm{y}$.

\section{Site 939}

Site 939 was drilled east of the Amazon Channel on the upper portion of the Amazon Fan (Fig. 1), whereas Sites 940 and 943 through 946 compose a series of sites drilled along the last active channel on the fan. Bioturbated overbank mud turbidites were sampled at Site 939. The Younger Dryas and isotopic events 2.2 and 2.21 are identified at this site (Fig. 13). Based on the recognition of these events, sedimentation rates increased downhole from $4 \mathrm{~cm} / \mathrm{k}$.y. in the upper portion of the site to $\sim 60 \mathrm{~cm} / \mathrm{k}$.y. in isotopic Stage 2 .

\section{Site 940}

Site 940 was drilled in the middle fan on the flank of the eastern levee of the Amazon Channel (Fig. 1). The Younger Dryas and isotopic event 2.2 is tentatively identified at this site (Fig. 14). Sedimentation rates varied from $4 \mathrm{~cm} / \mathrm{k} . \mathrm{y}$. in the upper portion of the site to $\sim 60 \mathrm{~cm} / \mathrm{k} . \mathrm{y}$. in isotopic Stage 2.

\section{Site 941}

Site 941 was drilled into the Western Debris Flow, a large surficial debris flow that fills the depression between two levees (Fig. 1). The Younger Dryas and isotopic events 2.2 and 2.21 are identified at 


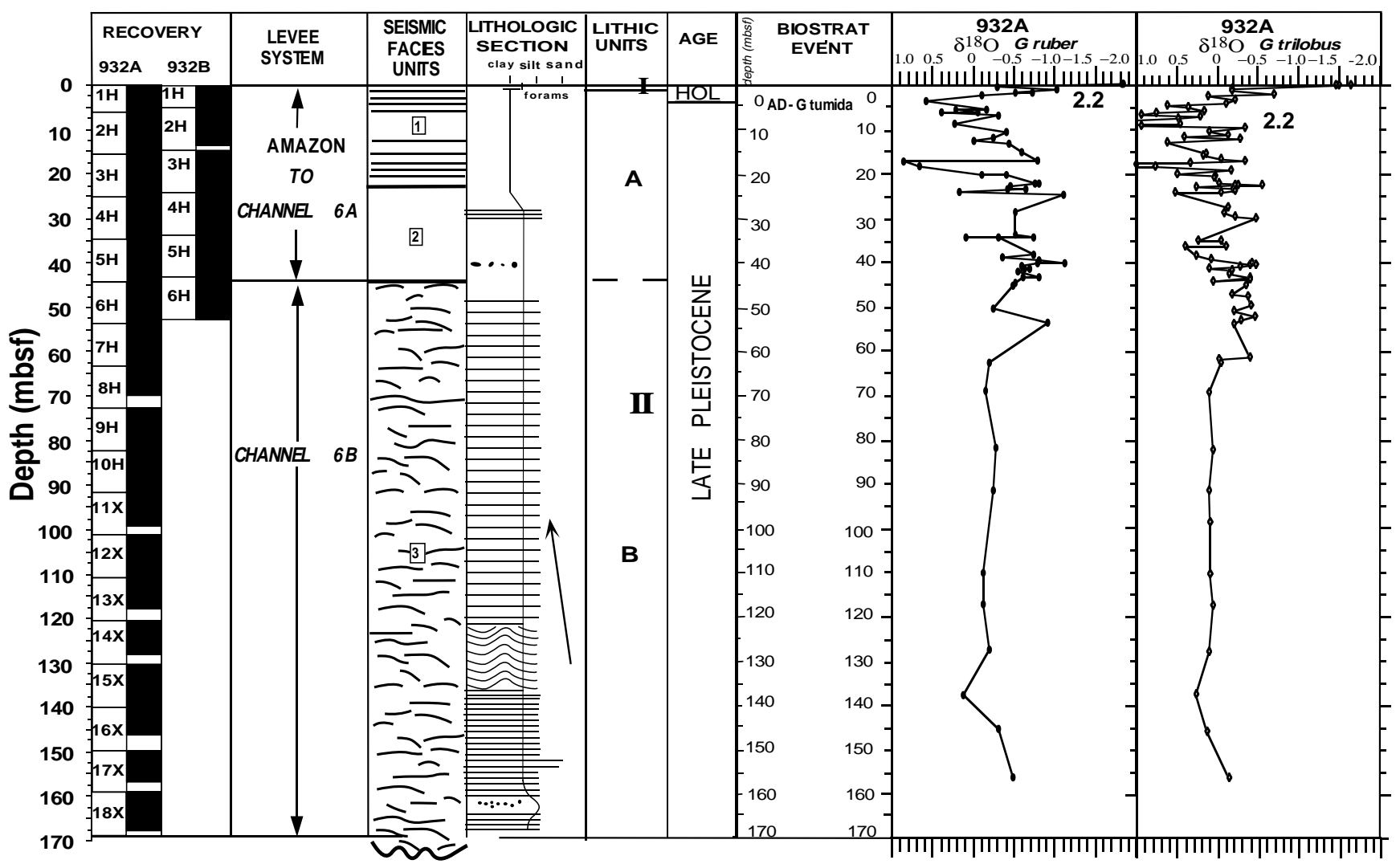

Figure 6. Summary of the $\delta^{18} \mathrm{O}$ stratigraphy with the lithostratigraphy, seismic stratigraphy, and biostratigraphy for Hole $932 \mathrm{~A}$.

this site (Fig. 15). The Stage 2 isotopic events are located in the debris flow, which is a mass transported sediment gravity flow unit. It appears that this unit was emplaced sometime during the deglaciation between 11 and $17.8 \mathrm{k} . y$. Sedimentation rates are low at this site, varying from $4-10 \mathrm{~cm} / \mathrm{k} . \mathrm{y}$. if the isotopic events in the debris flow are near their original position.

\section{Site 942}

Site 942 was drilled into the crest of an abandoned levee to the west of the Western Debris Flow (Fig. 1). The levee is of unknown origin because it is seismically obscured by the Western Debris Flow and cannot be tied to channel-levee systems on the central Amazon Fan (Flood, Piper, Klaus, et al., 1995). Isotopic events 1.1 to 6.3 were identified at this site (Fig. 16). Three subsurface carbonate layers correspond to isotopic events 5.1, 5.3, and 5.5. This site contains a complete record of the last interglacial (isotopic Stage 5) and sits on a Stage 6 abandoned levee. The small positive excursions noted at the other Amazon Fan sites in isotopic Stage 2 are not well defined at this site. Sedimentation rates at this site are very well constrained from the isotopic record and vary from $30-85 \mathrm{~cm} / \mathrm{k} . \mathrm{y}$. during the deglaciation, $35-60 \mathrm{~cm} / \mathrm{k} . \mathrm{y}$. in isotopic Stage $2,20-25 \mathrm{~cm} / \mathrm{k} . \mathrm{y}$. in isotopic Stage 3, 25-30 cm/k.y. in isotopic Stage 4, 80 to $125 \mathrm{~cm} / \mathrm{k} . \mathrm{y}$. in isotopic Stage 5, and 40-95 cm/k.y. in isotopic Stage 6.

\section{Sites 943 Through 946}

Sites 943 to 946 were drilled in the Amazon Channel on the middle and lower portion of the Amazon Fan (Fig. 1) to sample the coarsest sediment transported by recent turbidity flows. Site 943 was drilled in the channel, whereas Site 944 was drilled on the eastern levee downfan from the Amazon-Brown channel avulsion point. Sites 945 and 946 were located near the transition from the middle to lower fan. Site 945 was drilled into the channel, and Site 946 drilled into the levee. These sites contained little isotopic information due to the combination of low foraminifer abundance, discontinuous records, and the prevalence of mass transported sediments. Isotopic event 2.2 was identified in the upper portion of Sites 943, 944, and 946 (Figs. 17-20). Site 944 also contained the Younger Dryas Event and isotopic event 2.21. Sedimentation rate estimates vary in the deglacial portion of these records from 3 to $\sim 20 \mathrm{~cm} / \mathrm{k} . \mathrm{y}$., whereas isotopic Stage 2 sedimentation rate estimates varied form 475 to $>800 \mathrm{~cm} /$ k.y.

\section{DISCUSSION}

The rapid deposition rates found in continental margin records dilute foraminifers, and low abundances are problematic for the construction of detailed chronologies. A $\delta^{18} \mathrm{O}$ study could not be completed on the Bengal Fan (Leg 116) because of low foraminifer abundances and discontinuous records (Scott and Leger, 1990). Wefer et al. (1990) completed an oxygen isotopic study on the Peru Margin (Leg 112) by combining $\delta^{18} \mathrm{O}$ analyses of benthic foraminifers with the $\delta^{13} \mathrm{C}$ signal of organic carbon in the organic-rich sediments underlying the upwelling zone. On the Peru margin, prominent hiatuses were also discovered, but Sites 680B and 686B were drilled in less than $500 \mathrm{~m}$ water depth.

On the central portion of the Amazon Fan, the Holocene sediments have abundant and diverse assemblages of planktonic and 


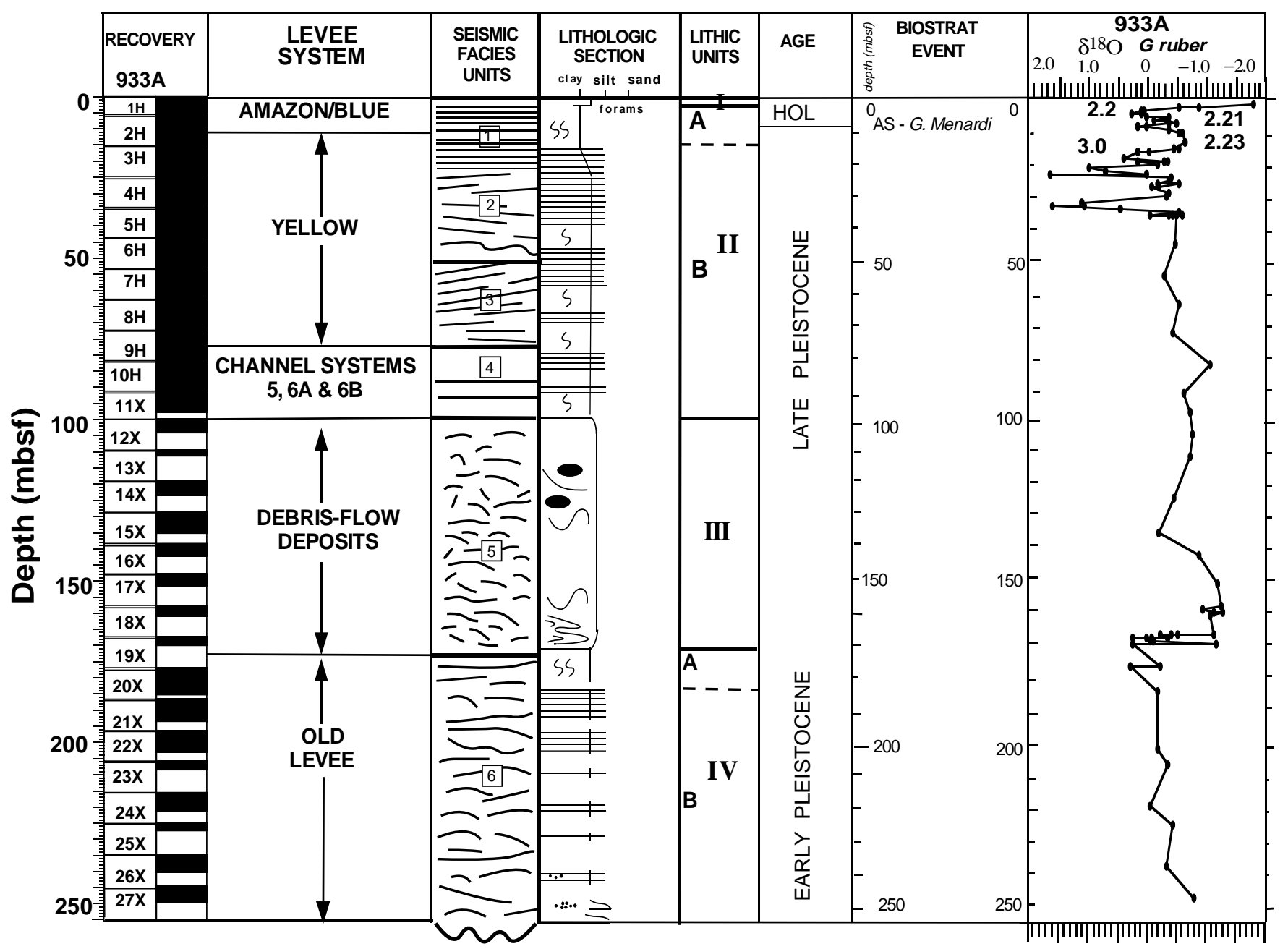

Figure 7. Summary of the $\delta^{18} \mathrm{O}$ stratigraphy with the lithostratigraphy, seismic stratigraphy, and biostratigraphy for Hole $933 \mathrm{~A}$.

benthic foraminifers. Below the Holocene/Pleistocene boundary, the sediments become mottled and dark, the abundance of carbonate and planktonic foraminifers decreases, the preservation of foraminifers becomes poorer, and the abundance of authigenic minerals increases, particularly iron sulfides. The increased abundance of authigenic iron sulfides at 5 to 10 mbsf may be the reason that conventional piston and gravity cores have not previously penetrated very deeply into glacial age Amazon Fan sediments. These older sediments are accessible through modern drilling techniques, and the recovery of fan sediments was successful on Leg 155 because drilling targets were well characterized seismically.

Because foraminifer abundances are too low for $\mathrm{AMS}-{ }^{14} \mathrm{C}$ dating in the glacial age sediment, the only way to construct age-depth models is through $\delta^{18} \mathrm{O}$ stratigraphies, along with biostratigraphic and paleomagnetic datums. Modern ratio mass spectrometers can analyze extremely small samples, as small as a single foraminifer specimen. However, extremely low microfossil abundances are a cause for concern in the construction of geochemical profiles such as $\delta^{18} \mathrm{O}$ stratigraphies. The low number of foraminifer specimens per interval may affect the isotopic chronology in slow sedimentation rate cores as a result of bioturbational mixing (Boyle, 1984). Zahn et al. (1986) suggest that benthic isotopic stratigraphies with reduced numbers of specimens do not have increased variability in cores with high sedimentation rates $(5-13 \mathrm{~cm} / \mathrm{k} . \mathrm{y}$.). Comparison of isotopic analyses based on multiple (2-50) and reduced (1-10) specimens of plankton- ic foraminifers from different depths on the Blake Outer Ridge sediment drift with sedimentation rates in excess of $20 \mathrm{~cm} / \mathrm{k} . \mathrm{y}$., show that there is an excellent agreement between multi- and few specimen isotopic stratigraphies in rapidly accumulating sediments (Johnson et al., 1988; Haskell et al., 1991). Problems associated with isotopic stratigraphies produced from a small number of specimens per interval should therefore be reduced to a minimum in Amazon Fan deposits, since these cores have sedimentation rates that range from 20 to $3350 \mathrm{~cm} / \mathrm{k}$.y. A more serious problem to the construction of isotopic stratigraphies in Amazon Fan sediments is the downslope transport of sediments in the form of debris flows, turbidites, and in channelized and unchannelized flows (HARs and HARPs). Debris flows more than $100 \mathrm{~m}$ thick occur near the present seafloor over most of the central fan and are easily recognizable. Lower parts of the debris flows are large slide-blocks, whereas the upper parts resemble muddy debris flows (Piper et al., Chapter 6, this volume). Foraminifer abundances are high in these debris flows (Fig. 2) and preservation is good, but the discontinuous nature of these sedimentary units precludes the construction of iterative chronostratigraphies such as stacked $\delta^{18} \mathrm{O}$ chronologies. Cores in the central portion of the middle fan have interpretable stratigraphies back to isotopic Stages 2 to 3, but generally have disturbed stratigraphies in isotopic stages older than Stage 2 or 3. Glacial sedimentation rates in these cores can reach up to $3300 \mathrm{~cm} / \mathrm{k}$.y. (Fig. 21), which may be too rapid for these sedimentary structures to remain intact over another glacial/interglacial 


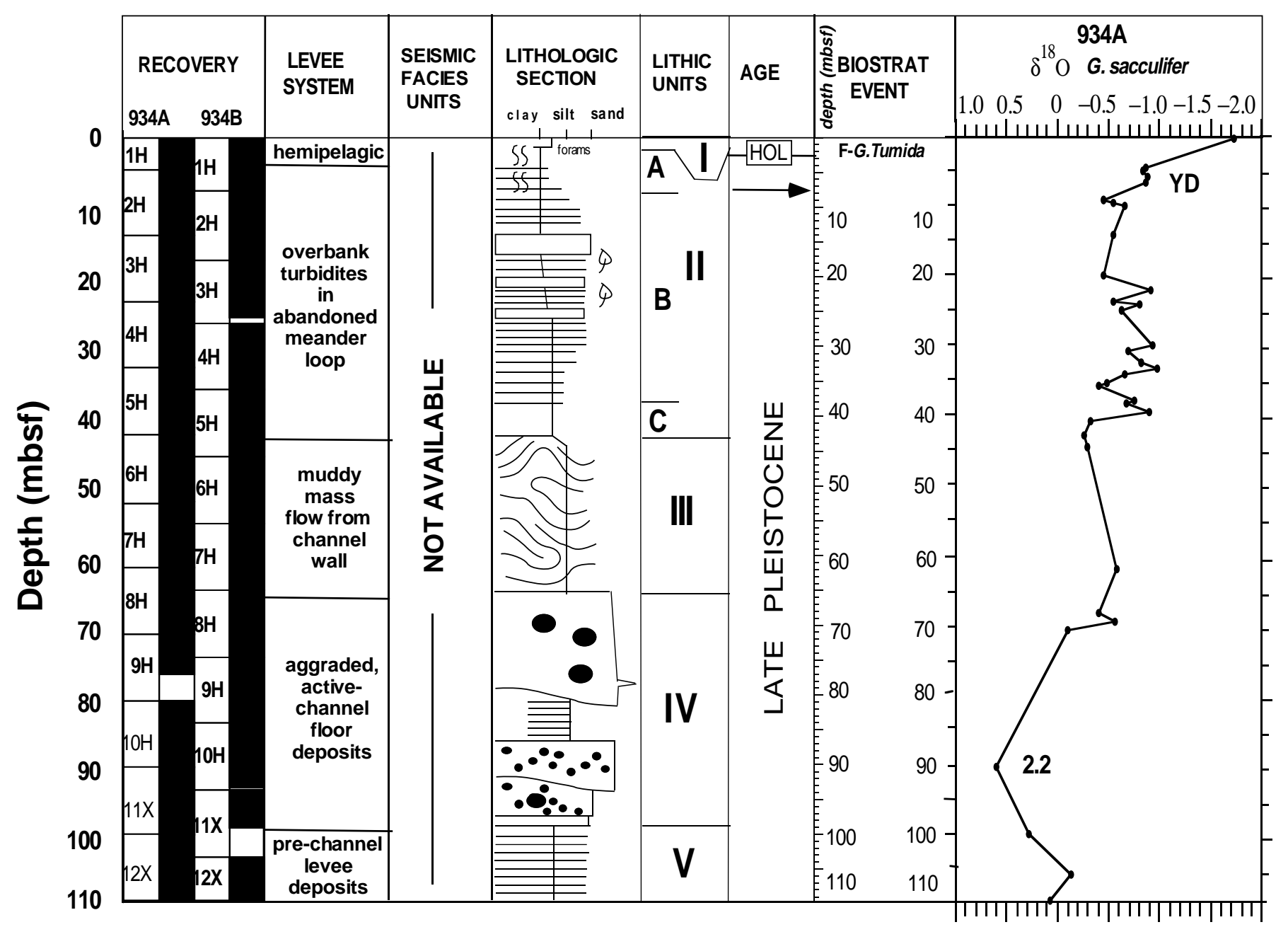

Figure 8. Summary of the $\delta^{18} \mathrm{O}$ stratigraphy with the lithostratigraphy, seismic stratigraphy, and biostratigraphy for Hole $934 \mathrm{~A}$.

cycle. The Unit R Debris Flow has disturbed the record of the previous interglacial (isotopic Stage 5) in all the eastern and central fan sites. High resolution stratigraphies are found on the upper fan (Sites 937 through 939), and off the central axis of the fan to the west of the Western Debris Flow (Site 942). Sites 937 through 939 penetrate into isotopic Stage 3 sediments. At these sites, bioturbated hemipelagic muds are separated by fine-scale mud and silt turbidites. Glacial sedimentation rates are on the order of $102-103 \mathrm{~cm} / \mathrm{k} . \mathrm{y}$. at these sites. Interpretable isotopic stratigraphies can be produced if the fine-scale turbidites are avoided. At Site 942, sedimentation rates are lower than on the central axis of the fan. Site 942 contains an excellent record of the last glacial lowstand (Stages 2-4) and the previous interglacial (Stage 5). Sedimentation rates at Site 942 (Fig. 22) are higher in the interglacial periods than the glacial periods. Sediment deposition patterns at Site 942 are different from the central Amazon Fan where sedimentation rates increase during the glacials and decrease during the interglacial. This antithetical deposition pattern suggests that the sediment source for Site 942 comes from a canyon to the north of the Amazon Canyon, and that sediment is focused at the site during sealevel highstands when along-shelf transport moves the Amazon discharge to the north away from the Amazon Canyon mouth. The three subsurface carbonate-rich layers observed at Site 942 correspond to isotopic events 5.1, 5.3, and 5.5, and were deposited during highstands. These carbonate layers are overlain by silt and fine sand turbidites. As the sea level fell, silt and fine sand turbidites separated the hemipelagic muds, suggesting a remobilization of transgressive highstand sand deposits during a period of falling sea level. Eventually, the shelf sands were removed, and only hemipelagic muds accumulated in the later portion of isotopic Stage 2. This site contains a unique record of the previous interglacial isotopic Stage 5.

\section{CONCLUSIONS}

Amazon Fan continental margin sediments have extremely high sedimentation rates during the last glacial period on the central axis of the fan. Downslope sediment depositional processes and hiatuses dominate the record on the central fan prior to isotopic Stage 3. The records of the mud-rich upper fan are not dominated by downslope sediment depositional processes and hiatuses. These records are expanded by fine-scale mud and silt turbidites that separate the hemipelagic bioturbated muds. Holocene sedimentation rates on the central fan vary from 3 to $10 \mathrm{~cm} / \mathrm{k}$.y., whereas glacial sedimentation rates can range up to $3300 \mathrm{~cm} / \mathrm{k}$.y. On the western portion of the fan, sedimentation rates are lower $(20-120 \mathrm{~cm} / \mathrm{k} . y$.$) . At Site 942$, the sediment record is not dominated by mass wasting process and hiatuses. Site 942 contains a complete record of the last interglacial (isotopic Stage 5), and sedimentation rates are higher during interglacial periods than during the last glacial period. Isotopic stratigraphies, along with biostratigraphic and paleomagnetic datums (Cisowski et al., this 


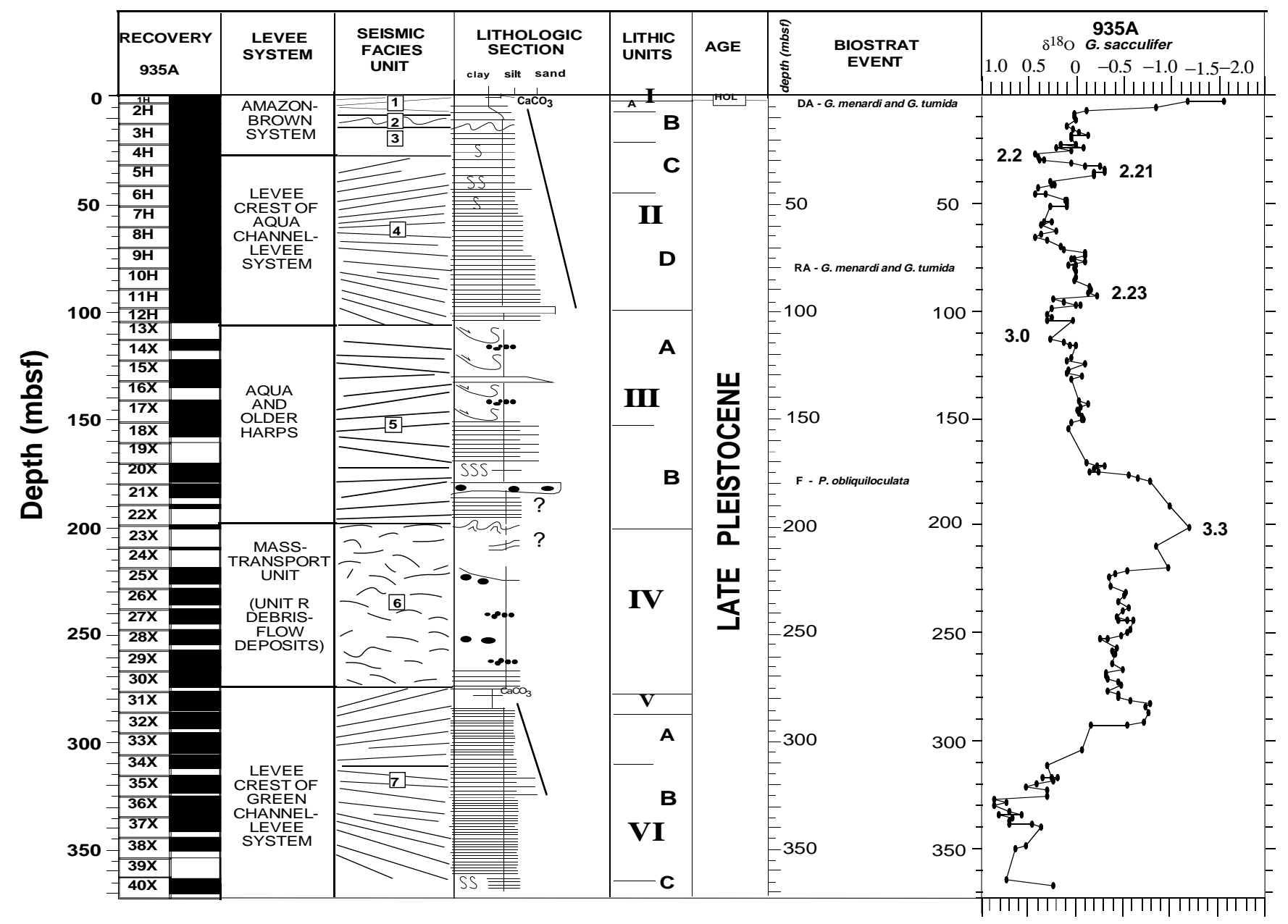

Figure 9. Summary of the $\delta^{18} \mathrm{O}$ stratigraphy with the lithostratigraphy, seismic stratigraphy, and biostratigraphy for Hole $935 \mathrm{~A}$.

volume) demonstrate that the upper levee complex on the Amazon Fan was deposited during the last glacial cycle and that the individual levee systems are not separated by interglacial deposits.

\section{ACKNOWLEDGMENTS}

We thank all of our shipboard colleagues who contributed to the collection of these cores and provided spirited intellectual discussions, particularly Jed Damuth, Roger Flood, and David Piper. We thank B. Genna, J. Fisher, and P. Price, who helped process samples at NCSU. This project was supported by the National Science Foundation (U.S.A).

\section{REFERENCES}

Alley, R., Meese, D., Shuman, C., Gow, A., Taylor, K., Grootes, P., White, J., Ram, M., Waddington, E., Mayewski, P., and Zienlinski, G., 1993. Abrupt increase in Greenland snow accumulation at the end of the Younger Dryas event. Nature, 362: 527-529.

Andrews, J.T., Tedesco, K., Briggs, W.M., and Evans, L.W., 1994. Sediments, sedimentation rates, and environments, southeast Baffin shelf and northwest Labrador Sea, 8-26 ka. Can. J. Earth Sci., 31:90-103.

Berger, W.H., Smetacek, V.S., and Wefer, G., 1989. Productivity of the Ocean: Present and Past: New York (Wiley).
Bond, G., Broecker, W., Johnsen, S.J., McManus, J., Labeyrie, L., Jouzel, J. and Bonani, G., 1993. Correlations between climate records from North Atlantic sediments and Greenland ice. Nature, 365:143-147.

Bond, G.C., Heinrich, H., Broecker, W.S., Labeyrie, L.D., McManus, J., Andrews, J., Huon, S., Jantschik, R., Clasen, S., Simet, C., Tedesco, K., Klas, M., Bonani, G., and Ivy, S., 1992. Evidence for massive discharges of icebergs into the North Atlantic ocean during the last glacial period. Nature, 360:245-249.

Bond, G., and Lotti, R., 1995. Iceberg discharges into the North Atlantic on millennial time scale during the Last Glaciation. Science, 267:1005-1010.

Boyle, E.A., 1984. Sampling statistic limitations on benthic foraminifera chemical and isotopic data. Mar. Geol., 58:213-223.

Bouma, A.H., Normark, W.R. and Barnes, N.E. 1989., Submarine Fans and Related Turbidite Systems: New York (Springer Verlag).

Broecker, W.S., Bond, G., Mieczyslawa, K., Clark, E., and McManus, J., 1992. Origin of the northern Atlantic's Heinrich events. Clim. Dyn., 6: 265-273.

Broecker, W.S. and Takahashi, T., 1984. Is there a tie between atmospheric $\mathrm{CO}_{2}$ content and ocean circulation? In Hansen, J.E., and Takahashi, T. (Eds.), Climate Processes and Climate Sensitivity, Am. Geophys. Union Monogr., 29:314-326.

Broecker, W.S., Peteet, D.M., and Rind, D.H., 1985. Does the ocean-atmosphere system have more than one stable mode of operation? Nature, 315:21-26.

Damuth, J.E., 1977. Late Quaternary sedimentation in the western equatorial Atlantic. Geol. Soc. Am. Bull., 88:695-710.

Damuth, J.E., Flood, R.D., Kowsmann, R.O., Belderson, R.H., and Gorini, M.A., 1988. Anatomy and growth pattern of Amazon deep-sea fan as 
revealed by long-range side-scan sonar (GLORIA) and high-resolution seismic studies. AAPG Bull., 72:885-911.

Damuth, J.E., and Kumar, N., 1975. Amazon Cone: morphology, sediments, age, and growth pattern. Geol. Soc. Am. Bull., 86:863-878.

Dansgaard, W., Johnsen, S.J., Clausen, H.B., Dahl-Jensen, D., Gundestrup, N.S., Hammer, C.U., Hvidberg, C.S., Steffensen, J.P., Sveinbj^rnsdottir, A.E., Jouzel, J., and Bond, G., 1993. Evidence for general instability of past climate from a 250-kyr ice-core record. Nature, 364:218-220.

Flood, R.D., Piper, D.J.W., and Shipboard Scientific Party, 1995. Introduction. In Flood, R.D., Piper, D.J.W., Klaus, A., et al., Proc. ODP, Init. Repts., 155: College Station, TX (Ocean Drilling Program), 5-16.

Flood, R.D., Piper, D.J.W., Klaus, A., et al., 1995. Proc. ODP, Init. Reports, 155: College Station TX (Ocean Drilling Program).

Flower, B.P, and Kennett, J.P., 1990. The Younger Dryas cool episode in the Gulf of Mexico. Paleoceanography, 5:949-961.

Fronval, T., Jansen, E. Bloemendal, J., and Johnsen, S., 1995. Oceanic evidence for coherent fluctuations in Fennoscandian and Laurentide ice sheets on millennium timescales. Nature, 374:443-446.

Gordon, A.L., 1986. Interocean exchange of thermocline water, J. Geophys. Res., 91:5037-5046.

Haflidason, H. Sejrup, H., Kristensen, D., and Johnsen, S., 1995. Coupled response of the late glacial climatic shifts of Northwest Europe reflected in Greenland ice cores: evidence from the northern North Sea. Geology, 23:1059-1062.

Haskell, B.J., Johnson, T.C., and Showers W.J., 1991. Fluctuations in deep western North Atlantic circulation on the Blake Outer Ridge during the last deglaciation. Paleoceanography, 6:21-31.

Imbrie, J.M., Hays, J.D., Martinson, D.G., McIntyre, A., Mix, A.C., Morely, J.J., Pisias, N.G., Prell, W.L., and Shackleton, N.J., 1984. The orbital theory of the Pleistocene climate: support from a revised chronology of the marine $\delta 180$ record. In Berger, A., Imbrie, J., Hays, J., Kukla, G., and Saltzman, B. (Eds.), Milankovitch and Climate (Pt. 1), NATO ASI Ser. C, Math Phys. Sci., 126: Dordrecht (D. Reidel), 269-306.

Johnson, T.C., Lynch, E.L., and Showers, W.J., 1988. Pleistocene fluctuations in the Western Boundary Undercurrent on the Blake Outer Ridge, Paleoceanography, 3:191-207.

Keigwin, L.D., and Jones, G.A., 1989. Glacial-Holocene stratigraphy, chronology, and paleoceanographic observations on some North Atlantic sediment drifts. Deep-Sea Res., 36:845-867.

, 1994. Western North Atlantic evidence for millennial-scale changes in ocean circulation and climate. J. Geophys. Res., 99:12397-12410.

, 1995. The marine record of deglaciation from the continental margin off Nova Scotia. Paleoceanography, 10:973-985.

Koblentz-Mishke, O.J., Volkovinsky, V.V., and Kabanova, J.G., 1970. Plankton primary production of the world ocean. In Wooster, W.S. (Ed.), Scientific Exploration of the South Pacific: Washington (Natl. Acad. Press), 183-193.
Manley, P.L., and Flood, R.D., 1988. Cyclic sediment deposition within Amazon deep-sea fan. AAPG Bull., 72:912-925.

Martinson, D.G., Pisias, N.G., Hays, J.D., Imbrie, J., Moore, T.C., Jr., and Shackleton, N.J., 1987. Age dating and the orbital theory of the ice ages: development of a high-resolution 0 to 300,000-year chronostratigraphy. Quat. Res., 27:1-29.

McManus, J. Bond, G. Broecker, W. Johnsen S., Laybeyrie, L., and Higgins S., 1994. High resolution climate records from the North Atlantic during the last interglacial. Nature, 371:326-329.

Nittrouer, C.A., and DeMaster, D.J., 1986. Sedimentary processes on the Amazon continental shelf: past, present, and future research. Cont. Shelf Res., 6:5-30.

Pisias, N., Martinson, D., Moore, T.C., Shackleton, N.J., Prell, W., Hays, J., and Boden, G., 1984. High resolution stratigraphic correlation of benthic oxygen isotopic records spanning the last 300,000 years. Mar. Geol., 56: 119-136.

Prell, W.L, and Damuth, J.E., 1978. The climate related diachronous disappearance of Pulleniatina obliquiloculata in Late Quaternary sediments of the Atlantic and Caribbean. Mar. Micropale., 3:267-277.

Prell, W.L., Imbrie, J., Martinson, D.G., Morely, J.J., Pisias, N.J. Shackleton, N.J., and Streeter, H.F., 1986. Graphic correlation of oxygen isotope stratigraphy: application to the late Quaternary. Paleoceanography, $1: 137-162$

Scott, D.B., and Leger, G.T., 1990. Benthic foraminifers and implications for intraplate deformation, Site 717, distal Bengal Fan. In Cochran, J.R., Stow, D.A.V., et al., Proc. ODP, Sci. Results, 116: College Station, TX (Ocean Drilling Program), 189-206.

Showers, W.J., and Bevis, M., 1988. Evidence for the source of the tropical meltwater spike from the Amazon Cone. Palaeogeogr., Palaeoclimatol., Palaeoecol., 64:189-199.

Wefer, G., Heinze, P., and Suess, E., 1990. Stratigraphy and sedimentation rates from oxygen isotope composition, organic carbon content, and grain-size distribution at the Peru upwelling region: Holes 680B and 686B. In Suess, E., von Huene, R., et al., Proc. ODP, Sci. Results, 112: College Station TX (Ocean Drilling Program), 355-367.

Zahn, R., Winn, K., and Sarnthein, M., 1986. Benthic foraminiferal $\delta^{13} \mathrm{C}$ and accumulation rates of organic carbon: Uvigerina peregrina group and Cibicidoides wuellerstorfi. Paleoceanography, 1:27-42.

Date of initial receipt: 22 January 1996 Date of acceptance: 17 September 1996 Ms 155SR-222 


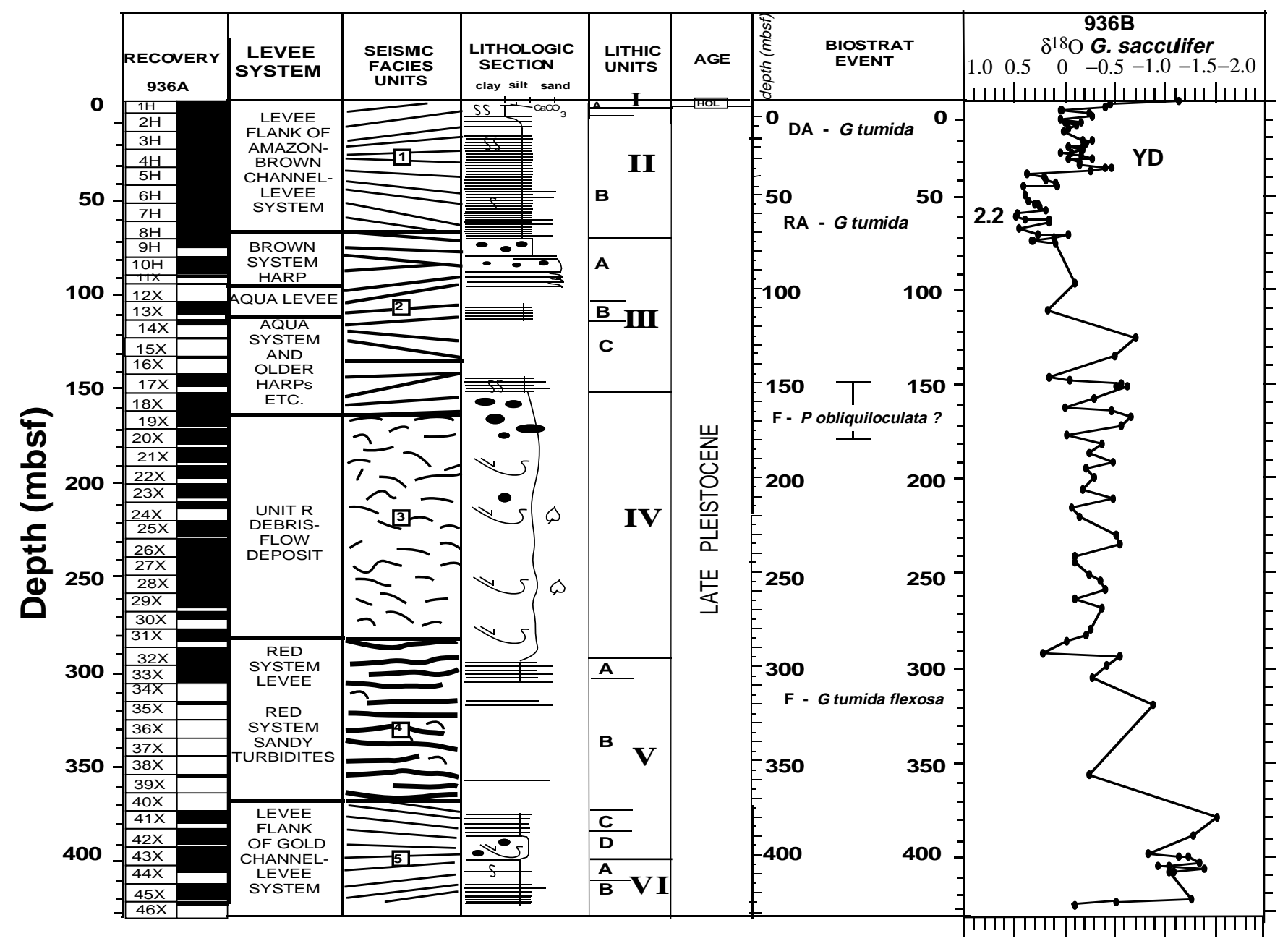

Figure 10. Summary of the $\delta^{18} \mathrm{O}$ stratigraphy with the lithostratigraphy, seismic stratigraphy, and biostratigraphy for Hole $936 \mathrm{~B}$. 


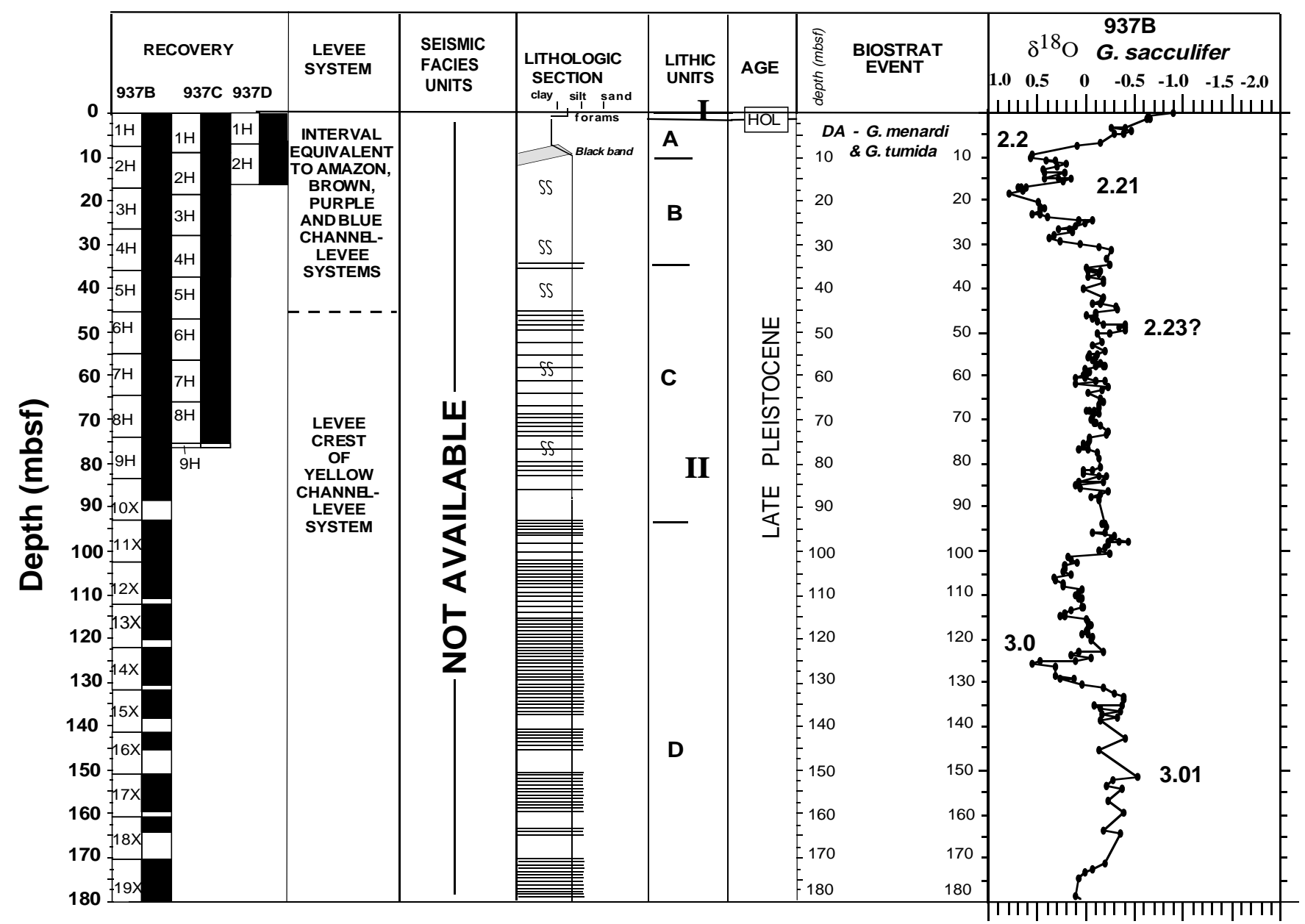

Figure 11. Summary of the $\delta^{18} \mathrm{O}$ stratigraphy with the lithostratigraphy, seismic stratigraphy, and biostratigraphy for Hole 937B. 


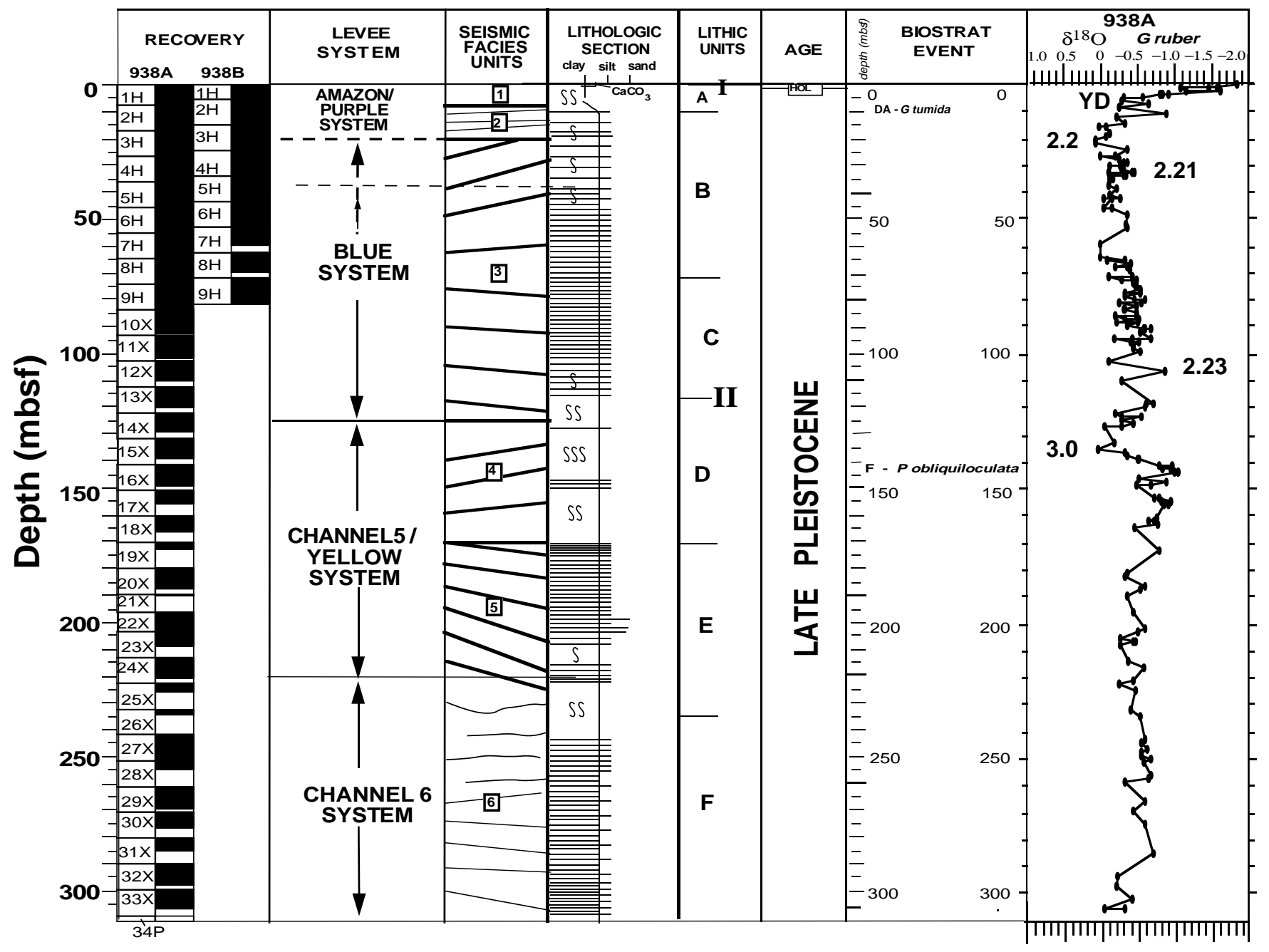

Figure 12. Summary of the $\delta^{18} \mathrm{O}$ stratigraphy with the lithostratigraphy, seismic stratigraphy, and biostratigraphy for Hole 938A. 


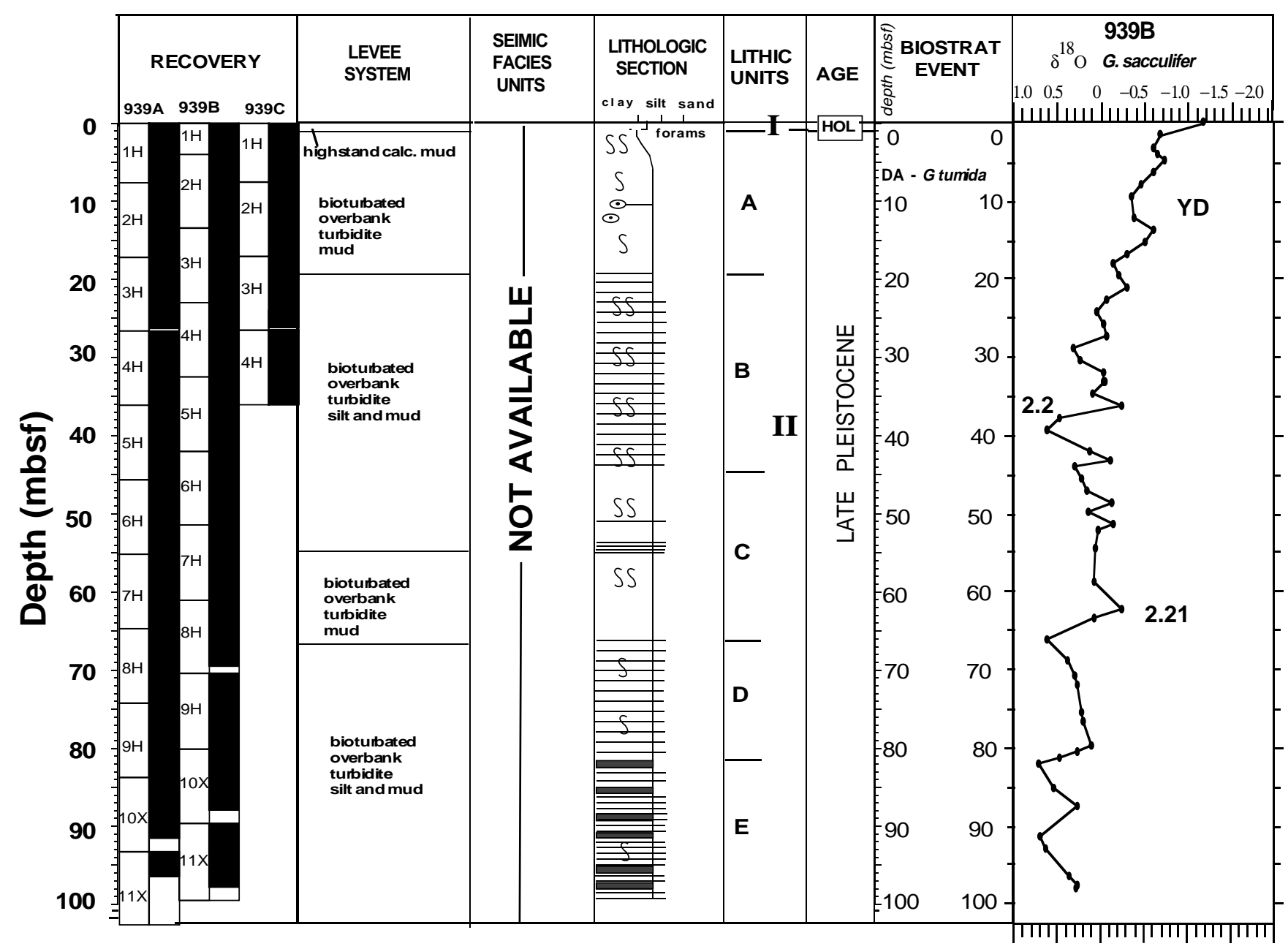

Figure 13. Summary of the $\delta^{18} \mathrm{O}$ stratigraphy with the lithostratigraphy, seismic stratigraphy, and biostratigraphy for Hole 939B. 


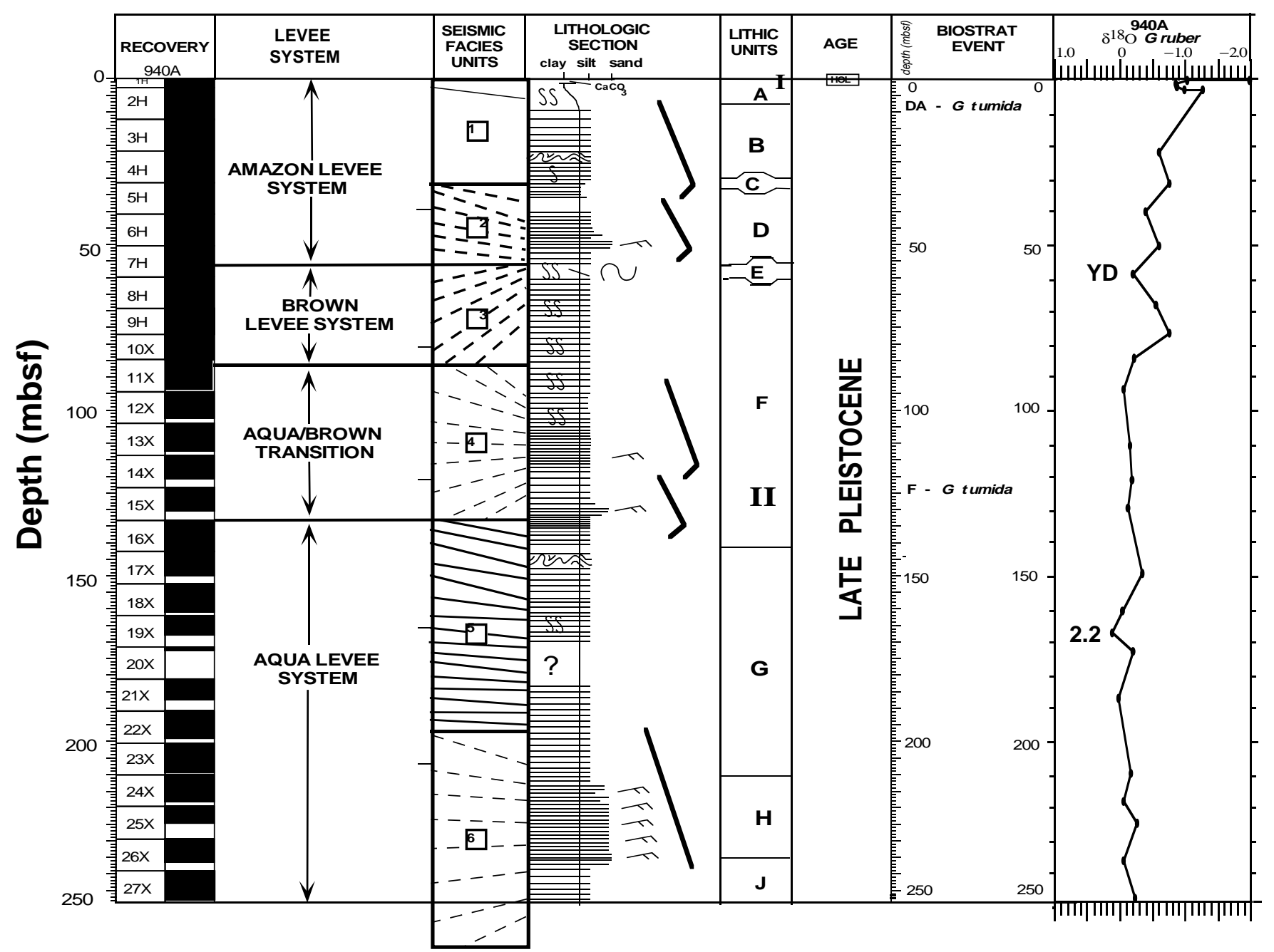

Figure 14. Summary of the $\delta^{18} \mathrm{O}$ stratigraphy with the lithostratigraphy, seismic stratigraphy, and biostratigraphy for Hole $940 \mathrm{~A}$. 


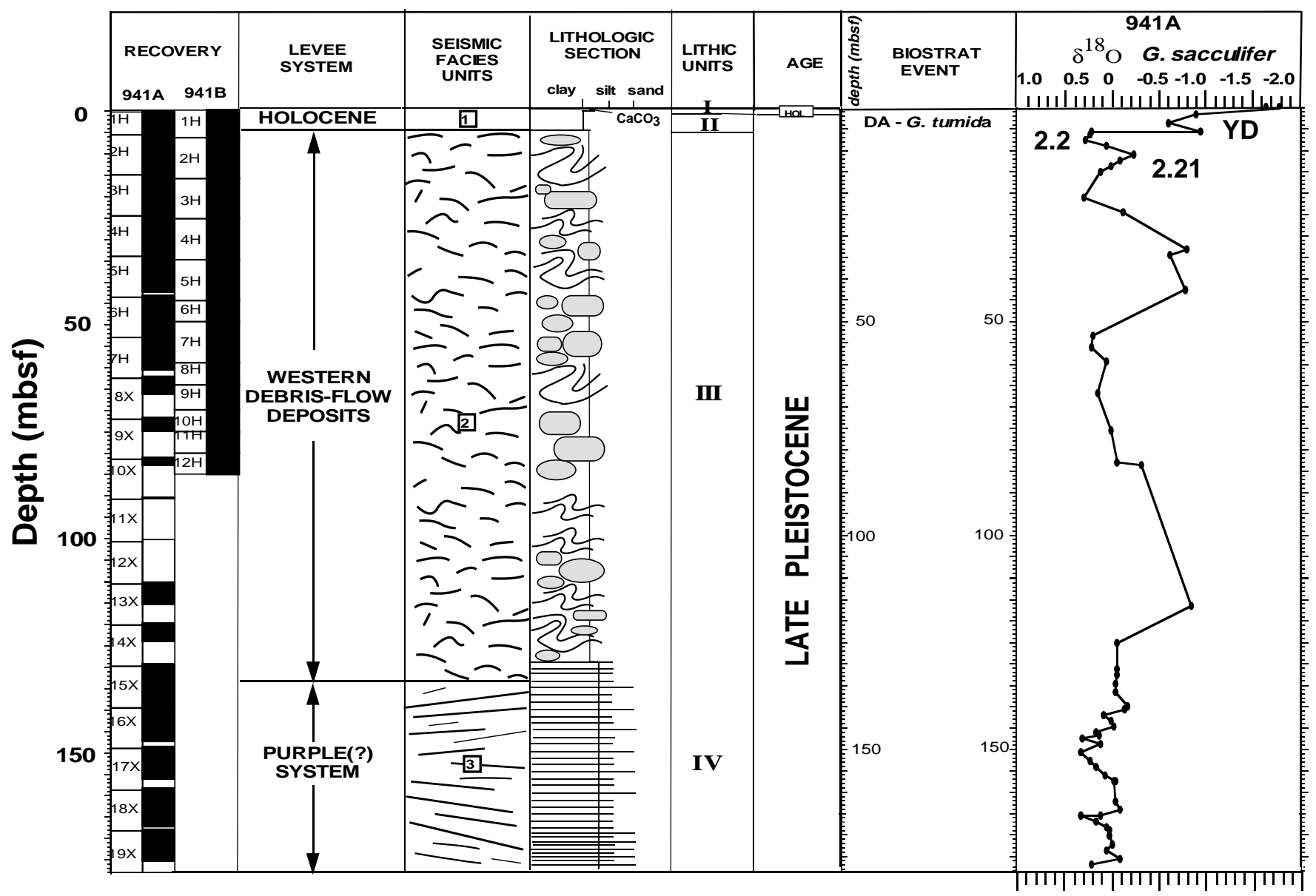

Figure 15. Summary of the $\delta^{18} \mathrm{O}$ stratigraphy with the lithostratigraphy, seismic stratigraphy, and biostratigraphy for Hole 941A. 


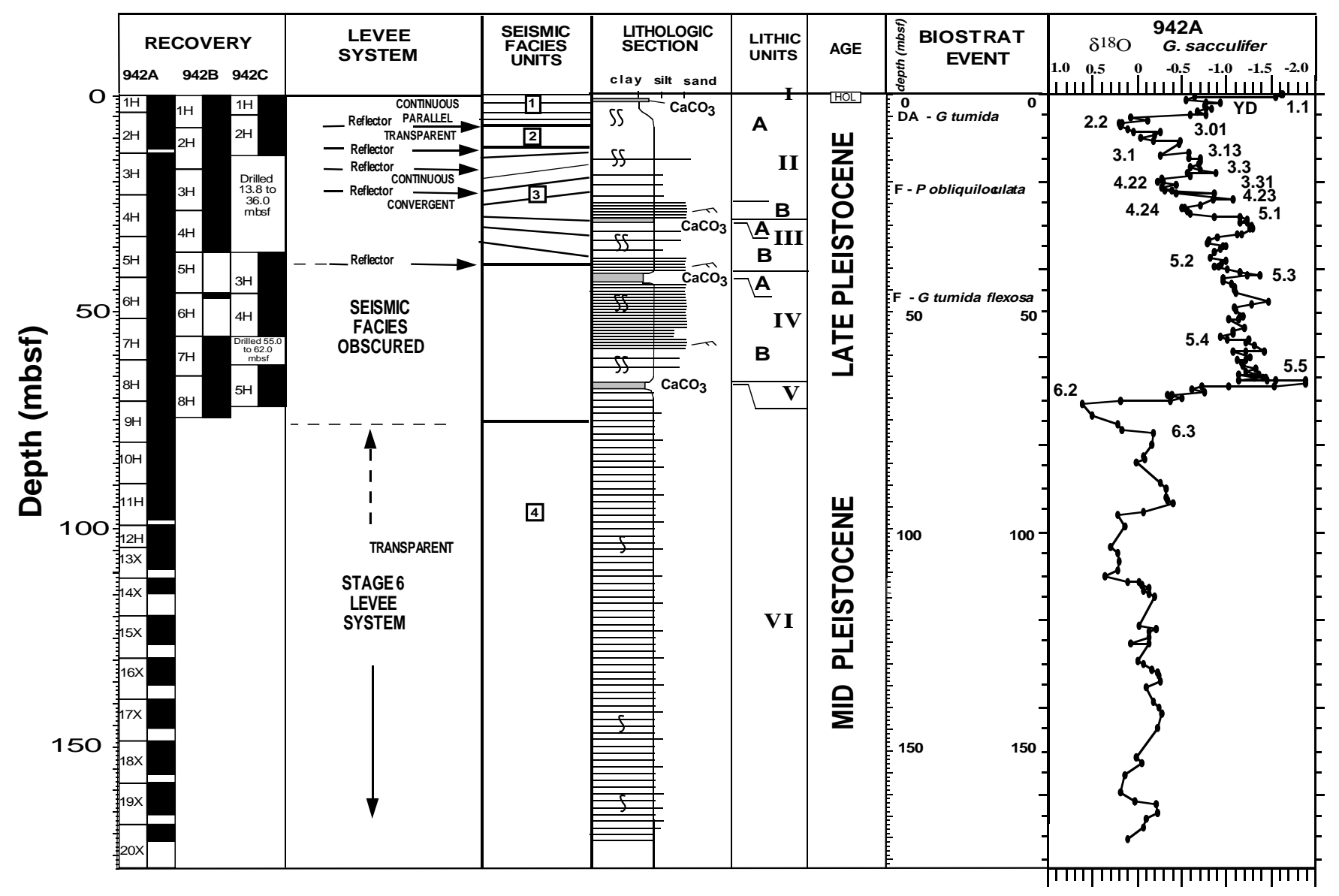

Figure 16. Summary of the $\delta^{18} \mathrm{O}$ stratigraphy with the lithostratigraphy, seismic stratigraphy, and biostratigraphy for Hole $942 \mathrm{~A}$. 


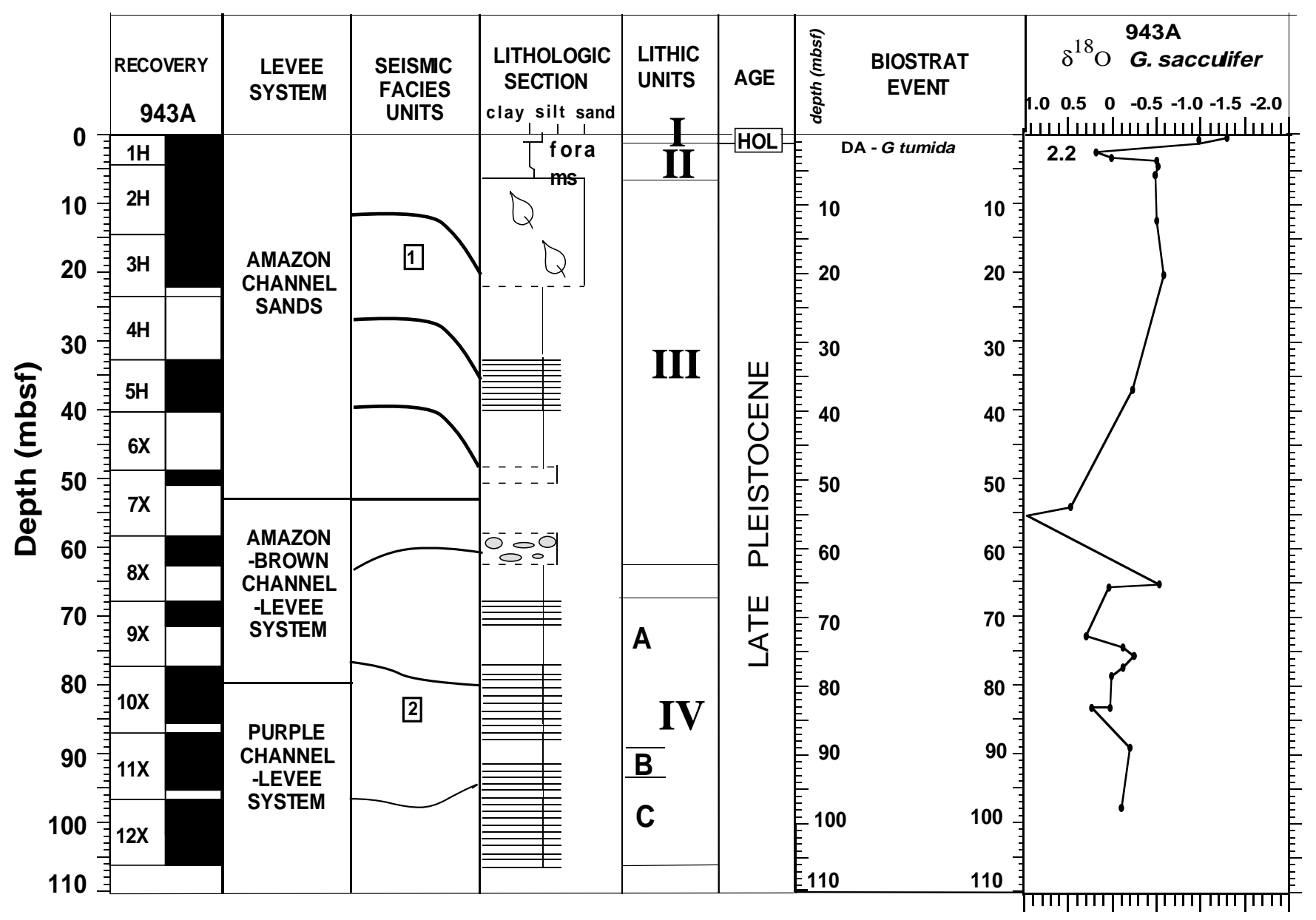

Figure 17. Summary of the $\delta^{18} \mathrm{O}$ stratigraphy with the lithostratigraphy, seismic stratigraphy, and biostratigraphy for Hole $943 \mathrm{~A}$. 


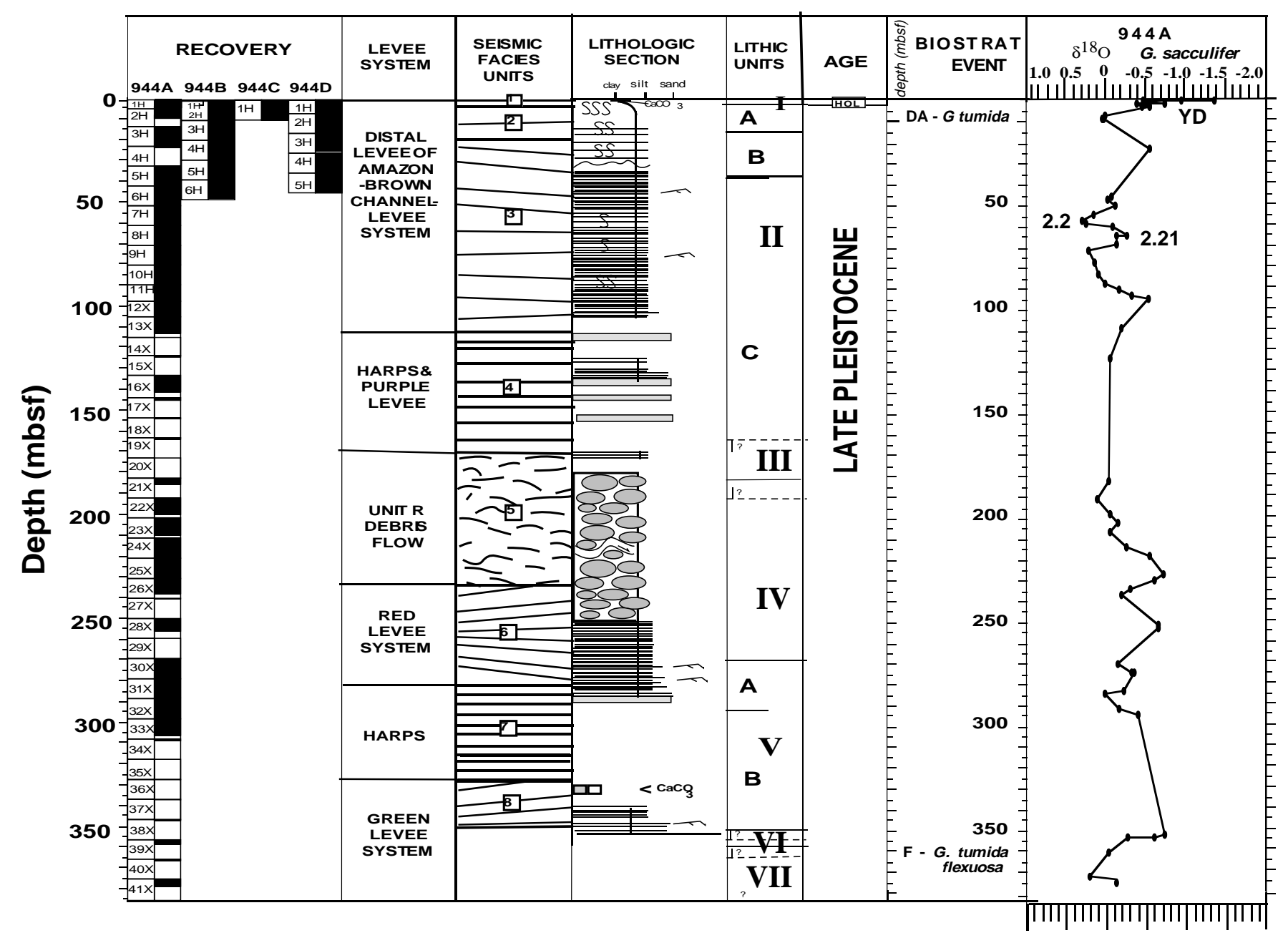

Figure 18. Summary of the $\delta^{18} \mathrm{O}$ stratigraphy with the lithostratigraphy, seismic stratigraphy, and biostratigraphy for Hole $944 \mathrm{~A}$. 


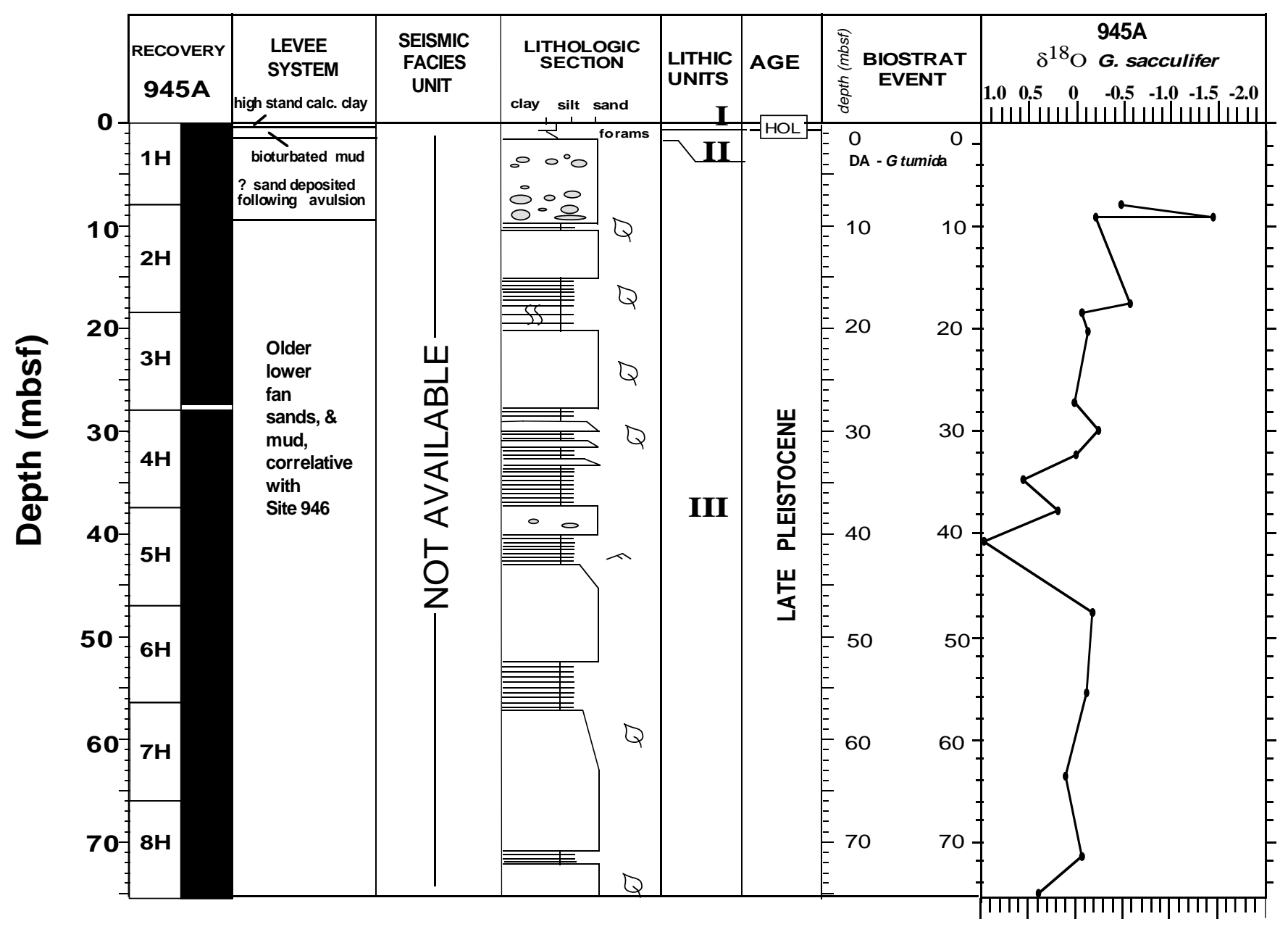

Figure 19. Summary of the $\delta^{18} \mathrm{O}$ stratigraphy with the lithostratigraphy, seismic stratigraphy, and biostratigraphy for Hole $945 \mathrm{~A}$. 


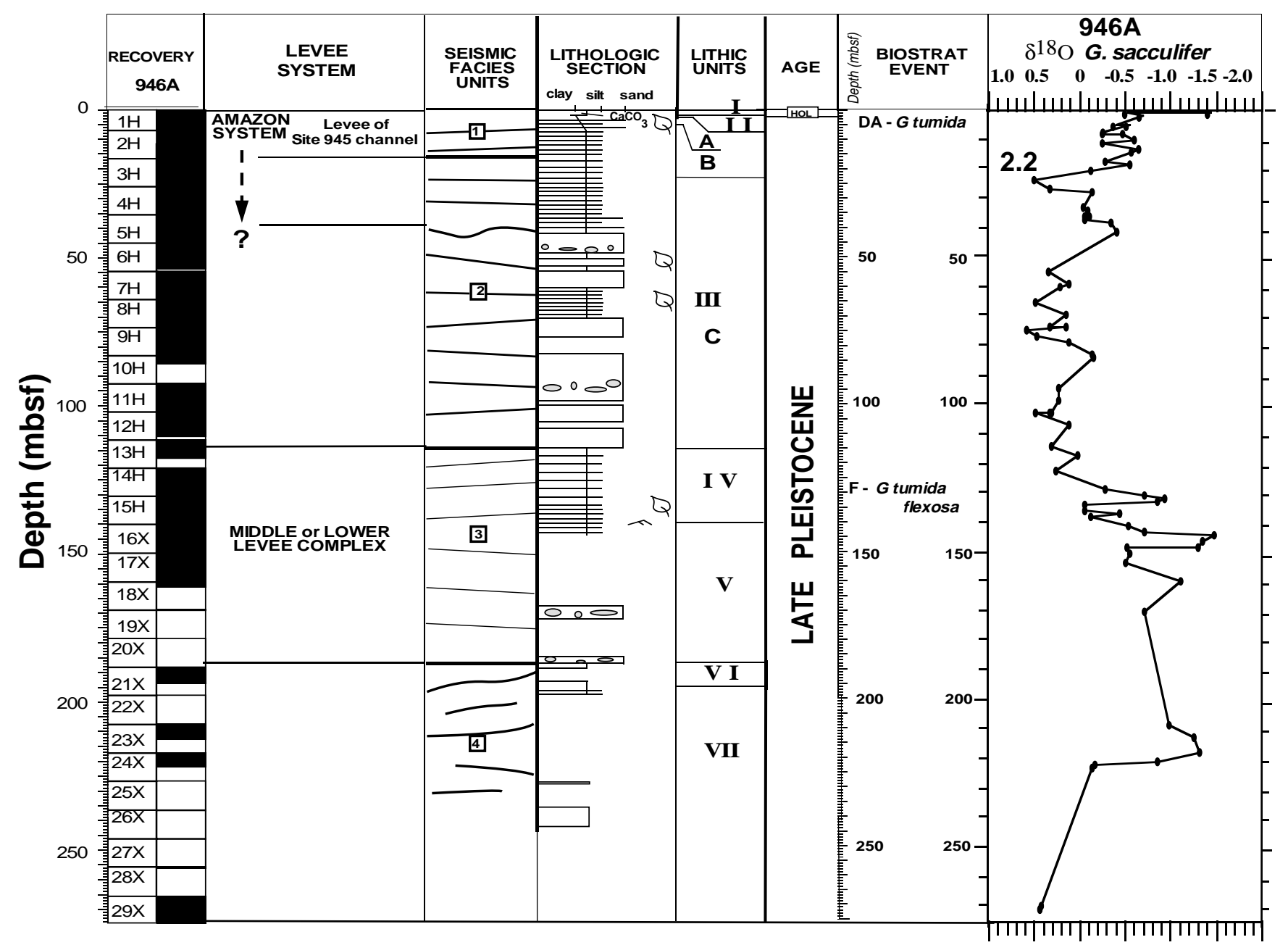

Figure 20. Summary of the $\delta^{18} \mathrm{O}$ stratigraphy with the lithostratigraphy, seismic stratigraphy, and biostratigraphy for Hole $946 \mathrm{~A}$. 
Figure 21. Sedimentation rate estimates for Leg 155 sites over the past 30 k.y. Sedimentation rates for the central portion of the fan increased greatly during the last glacial period.

Figure 22. Sedimentation rates for Site 942 on the western portion of the Amazon Fan. Note that sedimentation rates at this location are higher in the interglacials than during glacial periods.
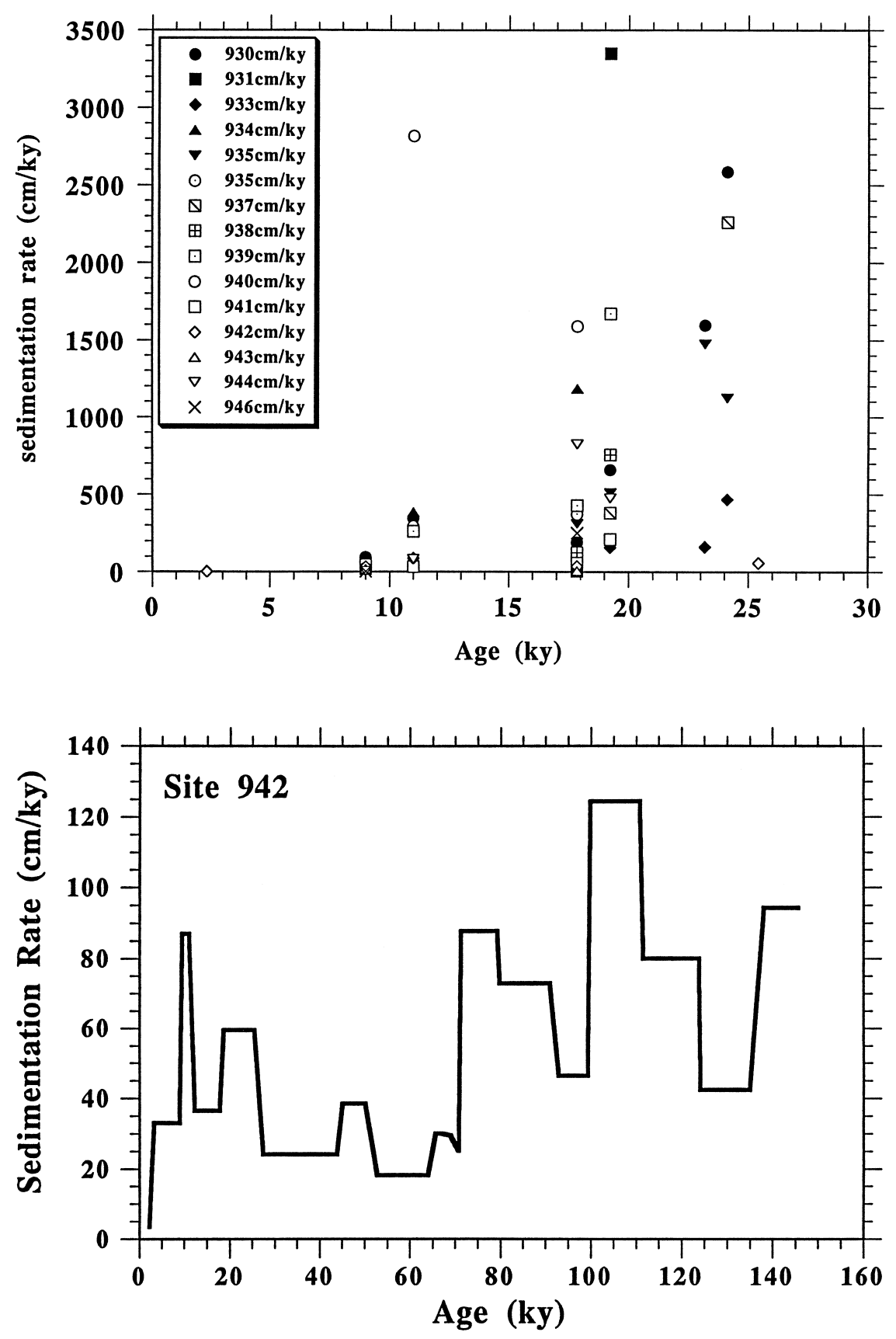